\title{
The politics of conservation planning: a comparative study of urban heritage making in the Global North and the Global South ${ }^{*}$
}

\author{
Elisabetta Pietrostefani, Nancy Holman*
}

\begin{abstract}
Urban heritage is the category of heritage that most directly concerns the environment of each and every person. Conservation or the integration of the built historic environment in city planning is typically viewed as a desirable undertaking, and policies to this effect are established as an integral element of planning in many countries. Our paper investigates the complexities at play between conservation planning structures, their applications and how these vary between contexts. It asks: how does conservation compare between planning systems of the North and South and what does this suggest about heritage value? Based on a survey of conservation planning systems in 5 countries, focusing on 5 city case-studies, this paper studies conservation's position within planning in current urban policy in different contexts. Our paper analyses how different planning systems have adopted and integrated urban heritage definitions and accordingly, how zoning techniques, governance levels and planning constraints have resulted in quite varied conservation planning outcomes not only between the North and South but between European examples alone. In exploring contexts where the desirability of conserving and enhancing the historic environment is overlooked, overturned or simply ignored despite the existence of conservation policies, this paper also explores the limitations regulation has in pinning down heritage values.
\end{abstract}

Key words: Conservation, planning, heritage, value, governance, urban, comparative analysis

Version: January 2020

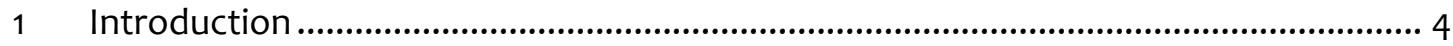

2 'Heritage creation' and its link to value ................................................................ 8

2.1 Heritage as part of planning? ................................................................... 8

2.2 Opposing values - instrinsic vs. economic ..................................................... 12

2.3 Total Economic Value .............................................................................. 13

3 Conservation planning in the Global North and the Global South ............................ 15

3.1 Starting points of heritage conservation ..................................................... 15

3.2 The evolution of planning regulation systems ................................................... 17

3.2.1 Initial designations of urban heritage areas ................................................ 18

3.2.2 Conservation planning: an integral part of cities .....................................19

3.3 From cultural to holistic non-use values ......................................................28

4 Heritage in Space ......................................................................................... 31

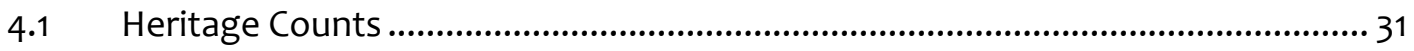

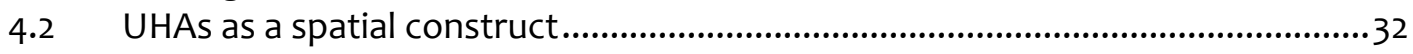

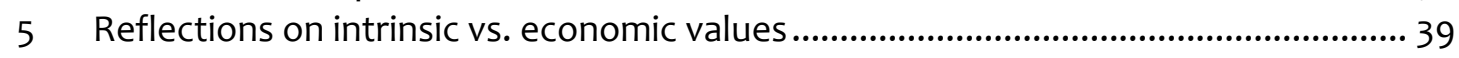

The role of public officials ........................................................................... 39

5.2 The value of land vs. heritage value...........................................................42

5.2.1 The extent of conservation constraints ..................................................42

5.2.2 Playing the Land Exploitation Game ................................................... 45

\footnotetext{
London School of Economics and Political Science (LSE)

* We would like to thank all the interviewees who participated in this study greatly enriching our analysis. We thank three anonymous referees as well as the editors of Progress in Planning, seminar participants in Gothenburg (AESOP 2018), London (LSE Economic Geography WIP) and London (Writing the World Seminar), in particular Austin Zeiderman, Alan Mace, Claire Mercer and Megan Ryburn, as well as Edward (Ted) Pinchbeck and Alessandro Balducci.
} 
5.2.3 Dissonance between legislation and practical urbanism............................... 48 


\section{Introduction}

Comparative studies on planning are never easy. What to leave in? What to exclude? Where to study? - are all questions that must be addressed and involve choices, value judgements and justifications in response. For our part, we have chosen to focus on a single aspect of historic conservation policy, the conservation of heritage areas in cities in the Global North and the Global South. We have chosen cities as there is generally higher pressure to develop land and largely due to the intensity of development, cities have far more heritage areas than do their rural counterparts. Conservation policy also illuminates the tensions present in the urban land nexus (Scott \& Storper, 2014) where a desire to protect common pool resources and a desire to develop land means that regulation and market forces can be brought into tight focus for examination. At the heart of the paper we believe that it is often this juxtaposition of desire to develop or a desire to conserve that offers a window into what is valued and how that value gets expressed. This is not to say that affective impacts of heritage do not matter, nor does this mean that historic structures and urban forms are valued more highly than new urban architecture or the many other cultural assets in cities. Rather we are actively choosing to focus on an aspect of planning policy and how it is practiced that purports to support cultural precepts of what matters in place. In so doing, we build a picture of how heritage policy gets applied in different contexts focusing specifically on the history of policy; the official discourse of planning regulation; and most importantly the nature of politics, culture and governance in the ultimate implementation and practice of policy. Our findings suggest that there is no clear model of Global North or Global South planning as context and circumstantial histories matter.

The objective of our paper therefore is to untangle how conservation planning systems and the local value of urban heritage are linked across several different planning contexts in the Global North and the Global South drawing on the idea of planning cultures (Booth, 2011; J Friedmann, 2005; Knieling \& Othengrafen, 2015; Othengrafen \& Reimer, 2013; Sanyal, 2005; Valler \& Phelps, 2018), which can be thought of as '... the collective ethos and dominant attitudes of planners regarding the appropriate role of the state, market forces, and civil society in influencing social outcomes' (Sanyal, 2005, p. xxi). As regulation has been argued to be a way of enforcing collectively rational behaviour and pinning down local values (Ahlfeldt \& Holman, 2015; Bevir et al., 2003; Holman et al., 2018) we see this as a good way of examining how heritage is valued in these diverse contexts. Through 30 in-depth interviews (see Appendix 1) and a comparative analysis of the ways in 
which heritage is regulated through the planning system in five case-study cities our paper will address our objective through an examination of four key areas. First, we will discuss the 'creation of heritage' and its link to value. Secondly, we will outline the evolution of heritage policy within the context of national planning systems that relate to each of our case study cities. Thirdly we will illustrate within our cities how these regulations have shaped space and in our final section we will examine the politics of enforcement. In so doing, we illustrate how various regulations and definitions of heritage reveal how heritage gets valued through planning policy and; how challenges to these values in the form of the application or the evasion of regulations occur and in turn how localised and variegated these values are in practice.

We take an interpretive approach, addressing the question through textual analysis of official documents, semi-structured in-depth interviews with planning officers and a policy mapping of both Northern and Southern cities illustrating the extent of the protected areas in each city (Bevir \& Rhodes, 2006; Hamin, 2003; Holman, 2014). This method, following Bevir and Rhodes (2006, 89), was chosen as it allows us to analyse the influence of regulation on value, given that 'people adopt beliefs and perform actions against the backdrop of an inherited tradition that influences them'. Traditions in this case are those formalised by conservation planning. The underlying challenge is that, in order to grasp how urban heritage is valued differently between countries, we must start by considering the legislative framework in order to gain a better understanding of how value emerges (Ahlfeldt \& Holman, 2015; Holman et al., 2018; Pani, 2017).

Our approach was chosen in order to come to terms with complexity. It rests on a philosophical analysis of meaning - in our case value - in formalised actions: the actions being legislation or the written plan and its implementation through government officials (Bevir \& Rhodes, 2006; Thomas, 2005). An interpretative approach distinguishes itself through theoretical views, that allow us to make sense of the governance of conservation planning in various contexts (Bevir et al., 2003) and respects the notion that planning cultures are dynamic (Bishwapriya, 2005, p. 22). It will allow us to make some initial deductions on how conservation planning plays out in various cities, and to interpret what these actions suggest about the negotiation between intrinsic and economic value. This of course takes into account that our analysis of meanings can grasp meaning only as part of a wider web of beliefs - the other elements of urban planning - knowing that heritage is only a small portion of them (Bevir \& Rhodes, 2006, 15). 
To work through specific examples of how heritage is valued in these local contexts, we are limiting our comparison of conservation planning to three contexts in the Global North and two in the Global South: England, France, Italy, Brazil and Lebanon using London, Paris, Milan, Rio de Janeiro and Beirut as case-study cities. Each planning system has its own peculiar starting point borne out of specific societal conditions and social models (see Newman \& Thornley, 1996; Watson, 2009; Marchettini et al., 2014; Minnery et al., 2012a; Sotomayor \& Daniere, 2018). In part this is what makes comparative planning led by an interpretive approach (Bevir \& Rhodes, 2006), that takes value seriously (Ahlfeldt \& Holman, 2015; Holman et al., 2018; Pani, 2017) such an effective way of examining how societies value particular aspects of physical and social infrastructures. It is these 'soft cultural' aspects of what is and is not valued that have for a large part produced differences in very similar planning systems (Ernste, 2012). Our first goal is therefore to build a thick description (Sanyal, 2005, p.12) of the various regulations and definitions of heritage in each national and more specifically urban context in order to reveal how societies value heritage, to then address challenges to these values and how systems, challenges and values are variegated across local contexts.

An interpretative approach also helps us avoid post-colonial discourses in addressing conservation in the Global South given that conservation is most often first formalised through legislation backed by colonial governments or similar. As we shall see, although the starting point for conservation planning in our southern case-studies is often adopted from western discourses, the systems evolve differently in light of contextual parameters, similar to our northern cases. We are thus able to carry out our exercise by adopting the same lens to our southern case-studies as we did our northern cases (Dolowitz and Marsh 2000; James and Lodge 2003; Balbo 2014, 270). Via this comparative analysis (Clarke, 2012; Sanyal, 2005), we denote relationships across and between 'northern' and 'southern' models allowing us to develop new theoretical models that avoid valorising western perspectives of planning (McFarlane, 2010).

The finer points of the analysis are rooted in a series of elite semi-structured in-depth interviews carried out between June 2016 and January 2017 in London, Paris, Milan, Beirut and Rio de Janeiro. All our respondents were asked similar questions to increase overall comparability. These included questions on historic and current trends in Urban Heritage Areas (UHA) designation and regulation; the relationship of this with policy implementation; and, for local planners, how residents interacted with these regulations. Given the geographic reach of this study, cities were chosen based on several factors. 
Practical considerations included the language competencies of the researchers, georeferenced data availability and existing contacts. More substantively we first wanted to have cities with a similarity in planning 'families' (Newman \& Thornley, 1996) with Milan, Paris, Beirut and Rio de Janeiro all being from the Napoleonic tradition. Here London was also included as a city with a very different planning history but also a strong culture of conservation policy. We also wished to look at country specific cities with interesting policy characteristics or planning challenges in the implementation of heritage policy. To this end we chose Paris as a city rich in heritage with quite rigid regulations (Cornu, 2003); London as a city with a significant housing crisis often attributed to restrictive planning; (see Cheshire \& Hilber, 2008; Cheshire \& Dericks, 2014; Hilber, 2015), Milan as a city with stringent regulations yet recent development trends (Savini \& Aalbers, 2016); Rio de Janeiro as a city where rapid urbanisation has led to the destruction of parts of the historic core of the city (Simon \& Braathen, 2019), and Beirut a city where postwar reconstruction has done more damage to the historic core than did the war (Puzon, 2019).

The interviewees were selected by integrating purposive and chain sampling techniques. First, officers occupying positions at different levels of government in handling the designation and management of conservation areas were contacted. They were asked to provide further contacts, which enabled access to representatives at all levels of government (state, regional, local). The interview strategy thus included combined elements of maximal variation and snowball sampling of interviewees nested into the initial purposive sampling (Creswell, 2009; Flyvbjerg, 2006). Interviewees included architects, planners, politicians, and association or NGO members and activists. Interviewees were encouraged to discuss the appropriateness of conservation planning in their local contexts given other urban pressures. The final sample includes 30 interviews, approximately six for each analysed city. Interviews were kept to under one hour and recorded, and interviewees were guaranteed anonymity (Creswell, 2009). This design allowed the participants to express diverse ideas and allowed us to react and follow up on emerging viewpoints.

In Section 2, our paper proceeds with a review both of urban heritage definitions in the theoretical literature and its different values. A clear theoretical sense of the units of analysis is necessary before initiating comparative analysis. Section 3 compares the development of conservation planning legislation at the national level in England, France, Italy, Brazil, and Lebanon, highlighting the differences between systems that have been considered best practice examples of conservation planning (Albrecht \& Magrin, 2015; 
Cornu et al., 2013). Given the complexity of these issues, the goal of this paper is not to provide a thorough description of each national conservation planning system (for which references will be provided), but to disentangle the elements, which will be most likely to influence how urban heritage is valued beyond its policy. Section 4 then moves on to see how these regulations developed at the national level are applied locally in our case study cities: London, Pairs, Milan, Rio de Janeiro and Beirut. Finally, in Section 5, we reflect on intrinsic vs economic value and the politics of policy implementation.

Our case-studies will reveal that although conservation planning originates in associated legal families, it is influenced by planning cultures and national frameworks, specifically the opportunities and constraints of national planning systems, which vary greatly (Clarke, 2012; Keller et al., 1996; Nadin \& Stead, 2008). In practice, conservation planning thus assumes many different meanings, and seems to be more closely linked to context than the authors would originally have thought, even in neighbouring European settings (John Friedmann, 2011; Newman \& Thornley, 1996). Our survey of case-studies suggests that local urban heritage value differs widely according to geographical location and historical context (Albrecht \& Magrin, 2015; Balbo, 2012; Batista \& Macedo, 2010; Cornu et al., 2013). If this is so, value systems are linked to the evolution of policy, which reacts to both location and history.

Finally, in our conclusion we discuss our understanding of the place of conservation within planning in current urban policy and what our findings suggest about how urban heritage is valued throughout different contexts. In concluding, we bring out more of the parallels between our northern and southern case-studies, to suggest there is no simple model that is particularly Northern or Southern.

\section{2 'Heritage creation' and its link to value}

\subsection{Heritage as part of planning?}

In many contexts, the conversion of the material city into an object of historic knowledge was provoked by the extensive and rapid transformation of urban space after the industrial revolution. This radical moment in the evolution of cities provoked the investigation and interrogation of the 'old city' creating a context in which the 'monument', the 'listed building' or the 'building of architectural value' became the starting point for conservation efforts. Definitions, speed of development and political appetite naturally varied across countries but the underlining principle of the retention of a sense of cultural and architectural inheritance remains the same (Cornu et al., 2012, 2013; Earl, 2015). 
As heritage preservation became more embedded in policy it moved beyond the ambit of antiquaries and architects making room for conservation policy to emerge. This shift allowed for function to be considered alongside form (Ashworth, 2011), enabling a broader policy scope, encompassing building ensembles, public spaces such as streets, stairs, green and open spaces and even entire neighbourhoods (Bernier et al., 2012; Choay, 1992; Habitat III, 2015; Tunbridge, 1984). In part, this was a recognition that it is the area and the setting that often creates social, cultural economic and environmental value in a city (Ashworth, 2011; Dalmas et al., 2015; Larkham, 1992; Licciardi \& Amirtahmasebi, 2012; Lowenthal, 1985; Pendlebury, 2009; Smith, 2006). This is because urban fabric often characterises an historic urban example, a unique population density, street pattern or other important urban morphological or cultural features (Tweed \& Sutherland, 2007). It is therefore intimately related to place-based planning and policy objectives or as noted by Burke (1976) 'preserving purposefully'. This makes UHAs ideally suited to our analysis as they form a part of heritage planning most closely aligned with area-based policies and imply both preservation and adaptive reuse.

The question then turns to how heritage is identified or 'created' via regulation, (Pendlebury 2009, 7). This typically results in a legal recognition or technical obligation to conserve urban heritage. As we shall see, the buildings, districts and other spaces designated by national, regional or local government are conceived in diverse ways using a variety of evidence and policy motivations. This variety frequently results in a diversity in the physical evolution of cities. The conservation of this stock includes stabilisation, rehabilitation, restoration, and other supportive activities, which vary greatly. In contexts where 'heritage creation' is effectively integrated into planning systems, conservation policy helps to underpin value by legally establishing protection for UHAs. It is therefore possible to unpick what is valued by first understanding what the regulations define as heritage and second examining how far the regulation extends in terms of limits to development.

Bearing in mind that legislation is known to follow some way behind public or societal attitudes (Larkham, 1992, 96), there is a broader conceptualisation of what is meant by the historic environment, which goes beyond what is designated by a governmental body. As noted by Rautenberg (2003), heritage specification is predicated on two processes; the first is founded in heritage legislation, which creates 'nationally legitimate' and 'legally binding' specifications with the second linked to socio-cultural factors emanating from what 'counts' as heritage to the population. For Rautenberg (2003), it is the social process 
of valuing that precedes the creation of legally binding designation. Therefore, before designation occurs, a form of appropriation materialises through actors such as nongovernmental organisations (NGOs) and community based organisations (CBOs) in the planning policy process (Balbo 2014, 272). In certain Southern contexts, these actors have increasingly filled the role of legislative agencies in light of a wide-range of government limitations. To facilitate an effective comparative exercise, however, this paper will limit itself to formalised processes, as it is within these moments of codification that societal preferences and values are formally underpinned.

The appreciation that heritage conservation as a part of planning comprises '... a culture of decision-making and the ways in which that culture is expressed in the institutions of the state and the legal system' we concur with Booth (2011 ,p. 16) that this illustrates that this '... shapes the way in which planning is understood and put into effect' (Booth, 2011, p. 25). This inevitably makes it a political enterprise further reinforced through the understanding that the city is a political actor in itself (Palermo \& Ponzini, 2010; Poulot, 2006). Thus, this historic and geographic construction establishes the un-designation or disregard for heritage as an equally political choice, which confirms that undesignated heritage is not necessarily without value.

We accept the limits of our study - it will not address civil society as a part of the governance system directly, in order to make the cases more easily comparable. We will, however, identify in which cases actors are more significant than others in terms of their formal and informal roles and powers (Minnery et al., 2012). As suggested by Balbo (2014, 282), we need to be aware in our reflection, of who is leading the governance of conservation within each of our reviewed planning systems. In cases where state governance is lacking, it may have been taken over by alternative entities.

The underlining factor is that urban heritage is an active process of identification (Smith, 2006). As this paper will show, although the starting point for conservation planning is the same or similar in most case-studies presented, the evolution is perhaps not so surprisingly, quite different. This is natural as the process of identification is necessarily linked to cultural, political and economic principles, which affect the intrinsic values of urban heritage. If these principles change or evolve, as argued by Pendlebury $(2009,7)$ '... not only can heritage identification change but it can also be contested'. ${ }^{1}$ The process becomes more complex when you consider the multitude of factors linked to conservation

\footnotetext{
${ }^{1}$ By intrinsic values we mean all intangible values associated with a given urban heritage, whether they be cultural, historical, social, or environmental.
} 
planning. For example, who is actually identifying urban heritage? And how does this change how value is determined? Is it central government, local government or communities? Moreover, how is value justified? For example, although urban heritage was traditionally linked to cultural concerns, (Pendlebury, 2009) this has changed as culture has been overtaken by issues like economic development or even sustainability. Here we see the frame of heritage subtly mutate in order to take on the dominant concerns of the day so that it remains relevant and maintains a certain gravitas (Gayego, 2014).

Values will unavoidably vary according to local historical and geographical frameworks. Given the past dominance of the North in shaping planning theory and practice (Watson, 2015), a comparison with the South can be useful in unpicking taken-for-granted assumptions about how planning addresses certain issues and re-questions differences between the North and South (McFarlane, 2010; Roy, 2009). Cities of the South are often conceptualised as a less-developed, which frequently implies an underdevelopment of their regulatory and governance systems (Roy, 2009). Comparative analysis between the North and South has therefore often been a question of policy transfer - where the adaptation of a Northern model to a Southern context is assessed. This vision is stressed within a heritage discourse, where the notion of patrimonialisation is repeatedly said to be a European one (Choay, 1992). Although the notion was certainly born in Europe, it seems unfair to presuppose that every effort to embed heritage conservation in the planning regimes of Southern cities derives from a European notion of patrimonial consciousness and an attempt to adapt this to a non-European context. As discussed, 'heritage creation' is an active process. It may certainly start as an exogenous concept coming from colonial compulsions, but the development of heritage in the planning paradigm deserves the benefit of doubt when considering national policies (Hanna, 2010). Moreover, it will allow us to assess the adoption of economic and culturally specific planning tools for every given city through the same lens: a view supported by many (Dolowitz and Marsh 2000; James and Lodge 2003; Balbo 2014, 270).

As we shall see, because every example is different, one cannot even identify a specific 'Northern' model that would apply to every Northern example, as there will always be variegation. Therefore, if we are to examine Northern cases through this lens expecting variation there is no reason not to apply this logic to Southern cases as well. In fact by proceeding in this manner we may more easily form an iterative loop whereby Southern case studies might offer insights into the re-theorisation of planning in the North (McFarlane, 2010; Roy, 2011). The lens will also help us to avoid problems linked with post- 
colonial theorisation and explore new theoretical possibilities (McFarlane, 2010). Comparative thinking is a well-suited strategy for revealing the distinctiveness and limits of particular theoretical claims, and also for formulating new lines of inquiry (Clarke, 2012; McFarlane, 2010; Sanyal, 2005). Only through such comparisons can an understanding of the place of conservation within planning in current urban policy be teased out, in order to speculate on future progression and possible responses (Balbo 2014, 270; Minnery et al. 2012).

\subsection{Opposing values - intrinsic vs. economic}

As discussed earlier, one way that heritage value can be expressed is through an examination of regulation creation, its application or its evasion. This is because it illustrates the tensions that are ever present between a desire to extract value from land and a desire, in this case, to retain values that are cultural and historic. In this section of the paper we move to consider urban heritage's use values (or the utility it may have in providing for a human want or need). As has been well established, markets and regulation interact in cities (Holman and Ahlfeldt 2015; Balbo 2014), making it necessary to analyse the relationships between planning systems and urban heritage's use values as well as its nonuse values.

Stemming from capital theory, Throsby (2006) describes heritage as an asset. The notions of 'capital' and 'heritage' present a number of similarities, they are both stocks of material assets, or of wealth, which can offer a source of income (Vernieres et al., 2012). Moreover, heritage as capital requires investment to maintain it (Ost, 2009). And conservation can, although this is not always the case, facilitate an investment process of allocating resources over time. For example, heritage buildings are re-used (adaptive reuse) for contemporary activities or develop a framework for tourism. Investment, however, also highlights the opposition between economic and intrinsic values of heritage and how they evolve at different rates (Throsby, 2010; Vecco, 2007). If we consider only the economic value, through revenue extraction and tourism exploitation of heritage, its other values will decrease slowly every year as we can see from Figure 1 (left side); the more urban heritage is exploited, the greater the loss of its intrinsic values (Zouain, 2002, 221). The search for an equilibrium, that maximises economic contribution while respecting the patrimonial aspects - the junction point of the two curves - is thus necessary for a 'living' urban heritage to exist, and in practice proves difficult. The paradox of urban 
heritage in the economy of any given city is that it is precisely the recognition intrinsic heritage values that allows for economic exploitation (Ost, 2009). ${ }^{2}$

As we see in Figure 1 after a subjective growth of intrinsic value, there is a corresponding rise in economic use-value ${ }^{3}$ (accessibility, use of the good) of urban heritage. The pursuit of this economic value begins to diminish the intrinsic value through its consumption (Zouain 2002) causing its shrinkage. Despite this the economic value is partially retained, as cities are still able to use structures even if the building stock loses its heritage related values. Given that conservation planning necessarily influences the determination of value through its identification process, it is important to consider these relationships. In fact, as we shall see, distinct conservation planning systems will give weight to one value over another determined in large part by societal desires illustrated by the production of stringent or lax regulation and the application of that regulation strictly or liberally. The stability of an urban ecosystem that integrates heritage into development decisions will therefore require a system of planning, be it state or non-state led, to manage this process.

Fig. 1 Intrinsic and economic values

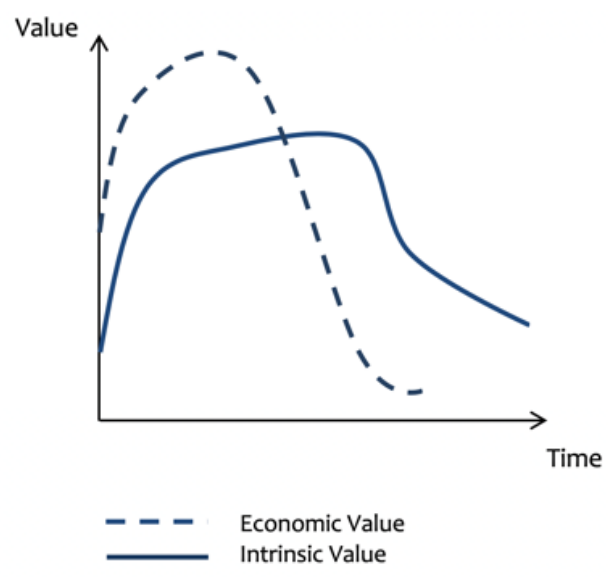

Note: Figure 1 is adapted from Zouain (2002)

\subsection{Total Economic Value}

Although we have established that urban heritage values sometimes work in opposition (economic vs intrinsic values), we need to delimit their multidimensional character (Navrud \& Ready, 2002; Vernieres et al., 2012). If we considered only the usevalue of heritage buildings, their value would often be lower than that of new builds and

\footnotetext{
${ }^{2}$ Non-use values are a pre-requisite to use values in heritage cases; without non-use values market transactions would not be generated and additional economic value would not be created.

3 Here we are speaking specifically of use value in its economic sense taken from environmental economics, rather than 'use-value' from the perspective of Marxian political economy.
} 
the restoration of urban heritage would always be considered an expenditure of resources that could be better used in other ways (Provins et al., 2005; Tuan \& Navrud, 2007). Urban heritage values are most simply understood through the well-known delineation of Total Economic Value (TEV) adapted from environmental economic theory where forms of value are monetary but also social, cultural/aesthetic, environmental and historical (Provins et al., 2005; Serageldin, 1999; Vernieres et al., 2012).

TEV considers both use and non-use values of urban heritage, appealing to the marketable and non-marketable sides of the equation (Pagiola, 1996). The use values of a heritage asset are the direct economic benefits that derive from it such as revenues or service transactions that increase in value because of their presence in heritage buildings (Vernieres et al., 2012). For example, lack of accommodation and supply of goods and services in an urban heritage environment can result in missed opportunities for induced growth, development and welfare. Non-use values, which can be divided between environmental, cultural, social and historic are often interlinked and refer to the assets people attach intrinsic socio-cultural values to (existence value), or that are closely associated with a way of life and its legacy (bequest value) (Serageldin, 1999; Smith, 2006). Existence value can be defined as the value placed upon the knowledge that a heritage asset exists. For a good to have existence value there are two necessary conditions: uniqueness and irreversibility. If these conditions are not present, then the good in question probably has a small or zero existence value.

These values are often tied to identity, aesthetic or architectural qualities, social structures and community values but also to more general urban atmospheres that are typical of specific urban environments. Finally, option value is heritage's 'insurance policy', referring to a heritage asset's possible future value or the value of the information we can derive from it (OECD, 2007). It supposes that even if there is no imminent plan for a heritage asset, its destruction will result in an irreversible impact and loss; there is a high value associated with not making irreversible decisions. Although TEV considers the values of urban heritage holistically, it cannot reflect them all nor explain all the relationships. Especially as, all cases are different; certain examples of urban heritage may present greater social values while others greater cultural ones.

Importantly for our analysis conservation planning systems and how restrictive they are will vary according to which urban heritage values they stress. Few planning systems will enforce regulations preserving all values, for if they did, we would be left with static historic cities not responding to contemporary urban needs brining us back to earlier 
notions of preservation instead of conservation (Ashworth, 2011). Indeed, the identification of all these values does not imply their use in practice (Vernieres et al., 2012, 72). TEV does, however, help to identify the different values that contribute to decisionmaking, these decisions are typically informed by conservation planning or the lack of such a system or the evasion of its regulations. Conservation planning is made complex as each value ascribed to urban heritage is contested by a variety of stakeholders participating in the 'heritage creation' process. This appeals to one of the old tales of planning: given a reality, can planning powers intervene to shift the balance of forces toward social goals in the ongoing processes of urban restructuring and, if so, with what tools? (Friedmann 2008, 250; Palermo and Ponzini 2012). In order to bridge conservation planning with the construct of value, we must attempt to explain the complex way in which value links back to the planning paradigm.

\section{Conservation planning in the Global North and the Global South}

\subsection{Starting points of heritage conservation}

The state of conservation of buildings and spaces can reflect many things: level of income, education, social and behavioural habits, ultimately the stratification of factors that contribute to defining the unique characteristics of a community. All these aspects are, however, in most cases, heavily influenced by the planning systems that underline the realities of conservation in a given country. The market has not proven to be a reliable institution for allocating present and future consumption; urban heritage is therefore strongly dependent upon regulation to pin down value and help determine supply (Ahlfeldt \& Holman, 2015; Rizzo \& Towse, 2002).

In the cases of England, France and Italy, the first examples of urban heritage legislation appeared over a century ago. Each system started with listed building designation and then evolved to include its own unique interpretation of UHAs. In England the process began with the 1882 Ancient Monument's Protection Act, updated in 1953 with the Historic Buildings and Monuments Act (Historic England, 2015a; Civic Amenities Act 1967, Chapter 69, 1967). In France a first law was introduced in 1887 and updated in 1913 with amendments that made provisions to classify buildings of historic or artistic value to the public without the owner's consent, public or private, and entailing the obligation to not modify the building, or any section of it without obtaining permission from local government (Cornu et al., 2013; Devernois et al., 2014). In Italy the Legge Nasi (n. 185/1902) first established a list of national monuments and was further developed by the Legge Bottai (n. 1089/1939) which addressed the needed protection of structures of artistic or 
historic interest (Carughi, 2012). Article 9 of the Italian Constitution, moreover, states the need to protect and enhance both the landscape, historical and artistic heritage of the nation (Cosi, 2008). In each case, the legislative framework started with architectural inscriptions within a heritage legislative framework where individual buildings are classified or listed in the French case, given a Grade I, II or II* in the English case, or classified as being of 'great cultural interest' (monumenti) or of minor architectural value or 'other interest' (beni architettoici) in the Italian case (Ministero dei beni e delle attività culturali e del turismo, 2016).

Similar to our European cases, the legislative framework in Brazil and Lebanon also began with architectural inscriptions. In both cases, the first examples of urban heritage legislation appeared in the 1930s. The first conservation law in Lebanon dates back to the French mandate (1920-1942) and stipulates the protection of urban heritage within all artefacts dating before 1700 through the Antiquities Law (166/LR - 7/11/1933) (Audrerie, 2000; Tyan, 2012). It also declared that immoveable objects dated after 1700 may be preserved if special public interest of historic or artistic value can be ascertained (Toubekias \& Dentzer, 2009, 16). Merely 20 years after the monuments law in France, Lebanon had introduced a law that recognised the diverse values of stand-alone buildings, both historic and artistic and similar to its northern counterparts, the legislation specified two ways of inscription. In Lebanon a building could either be inscribed by ministerial decree or classified by the Head of State (Article 26) on an inventory of historic monuments managed by the General Directorate of Antiquities, a part of the Ministry of Culture (Hanna, 2010; Tyan, 2012).

As with Italy, the first reference to immoveable heritage in Brazil is in the Constitution (1934). It states that 'it is the responsibility of the Union and the States to protect natural beauties and monuments of artistic and historical value' (Castriota, 2008; Silva, 2012, 120). The 1937 Constitution then transmitted the responsibility to protect historic monuments to municipalities and swiftly recognised the natural value of landscapes (F. F. da Silva, 2012, 120). Decree-Law 25/1937 created the four Livros de tombo (Inscription books), which interestingly divided heritage assets both by category and type of values between Archaeology, Ethnography and Landscape, History, Fine Arts and applied arts (Batista \& Macedo, 2010; Camara dos Deputados, 2010; Dos Santos \& Telles, 2017). Heritage buildings or monuments could thus, in theory, be listed in one or more of these registers. This is different from other formalizations of value present in our casestudies, as the division of the books underline the importance of identifying the principle 
type of value recognised in a building, thus acknowledging the multidimensionality of intrinsic heritage values. According to the legislation, an asset recognised for its historical value needs to be inscribed in the appropriate book specific to it and not in any other, st this would risk invalidating the inscription (F. F. da Silva, 2012, 124). Decree-Law 25/1937 also made a first allusion to the concept of historical areas, neighbourhoods, sub-cities or citycentres (tombamento do conjunto urbano) to be inscribed in any of the four books. Article 17 of 25/37 specifies that in the neighbourhood of the listed building 'it is not possible to ... make a construction that prevents or reduces visibility' (Decreto-lei 25/37| Decreto-lei ${ }^{\circ} 25$, de 30 de novembro de 1937, 1937).

According to both Brazilian and Lebanese legislation, assets must be legally preserved, and their owners should maintain their original features. In the Lebanese case, no alterations should be carried out without the approval of the General Directorate of Antiquities. In Brazil, there are different categories of building listing, similar to our northern case-studies. The first, called tombamento stipulates the conservation of all original elements of the building, interior or exterior. The second, bem preservato, only protects exterior elements of the building (facades, roofs, etc). The third category, bem tutelado, are buildings only semi-protected, demolition or changes are permitted, however new construction needs to follow the general aesthetics of the surrounding (R. C. M. Da Silva, 2012).

Social concerns are thus formalised through the recognition of non-use values of urban heritage, making the continued existence of these buildings important. In all our case-studies, urban heritage was thus first 'created' through the recognition of the intrinsic values of individual architectural examples, frequently tied to notions of nationhood and culture (Choay, 1992; Pendlebury, 2009) The non-use values of urban heritage, notably the cultural, social and historic values making the continued existence of these buildings important, were the first to be emphasised by conservation planning. The differentiation of the various levels of importance of these buildings highlighted the idea that even structures of humble origins may also carry significance.

\subsection{The evolution of planning regulation systems}

From their inception, up and to the introduction of modern town planning systems in Italy (1942), England (1947) and France (1954), conservation policy grew slowly but progressively (Mehl-Schouder et al., 2015; Newman \& Thornley, 1996; Scattoni \& Falco, 2011) reflecting the dynamism of planning as a social practice (Sanyal 2005). In our two southern contexts, while notions of heritage areas in Brazil developed steadily, similarly to 
our northern case-studies, in Lebanon the political will towards conservation was sporadic and rarely followed through.

\subsubsection{Initial designations of urban heritage areas}

In England, this came in the shape of the 1931 Ancient Monuments Act, which introduced the idea of preservation schemes and extended this to the area directly surrounding an ancient monument controlling development nearby. In the cases of France and Italy, although UHAs were not identified within urban codes, they were identified from an environmental perspective, including adding UHAs into valued natural environments. In Italy the law (n.1497/1939) refers to 'natural goods' including 'beautiful ensembles'4 which are 'complexes of immobile things (buildings) that hold aesthetic or traditional values' (Carughi, 2012; Giannini, 1976).

In France, a similar definition relating to the idea of a 'heritage ensemble' is inscribed through the 1906 lois des sites (updated in 1930). This law complemented the 1913 historic monuments law by extending protection to historic sites (Assemblée Nationale, 2017). By definition, it protected areas presenting landscape value, both rural and urban it is the oldest indication of value being attributed to landscape addressing another layer of urban heritage non-use values (Ministère de la Culture et de la Communication Direction Générale des Patrimoines, 2012). This law is part of the French environmental code, and although, as specified, it isn't directly addressed at UHAs it has resulted in the protection of many equivalent areas. One of the most famous is in Paris (Figure 4) and was inscribed in 1975. It covers 4400 ha (42\% of the surface area of Paris) including almost all of the 11 first arrondissements and parts of the $16^{\text {th }}$ and $17^{\text {th }}$ (APUR, 2004; IAU-IDF, 2013). Both these initial Italian and French laws indicate that although urban heritage areas are conceptually separate from natural preserved areas, they have links that should not be overlooked. Indeed, the reason why techniques for the economic valuation of natural amenities have been successfully transposed to the historic environment lies in their many similarities (Provins et al., 2008).

Following the 1937 law, Brazilian municipalities started pursuing conservation at the local level in the 1970s. In Rio, Lucio Costa lobbied to change the concept of urban conservation from isolated buildings to urban heritage areas. Contemporaneously Rodrigo Mello Franco was active within the National Institute of the Historical and Artistic Heritage (IPHAN) based in Rio, and advocated the concept of urban fabric and buildings as homogenous ensembles (Batista \& Macedo, 2010; R. C. M. Da Silva, 2012). Some effort was

\footnotetext{
${ }^{4}$ Denominated in Italian legislation as 'bellezze d'insieme'.
} 
also made in Lebanon to advance conservation planning. Beirut's Urban Master Plan (1964) initiated a concern for conservation of historic areas. During Amin Gemayel's (1982-88) mandate as president, two decree-laws were issued. The law of urbanism 9/9/1983 n69 required the delimitation of archaeological areas and other historic zones presenting aesthetics, historic or ecological value (Hamdan et al., 2012). The law of construction $16 / 9 / 1983 n^{\circ} 148$ subjects buildings of historical importance to construction permits to be evaluated by the General Directorate of Antiquities (Fischfisch, 2011). Other attempts in Lebanon were through decentralisation efforts. Article 74 of the municipal law of 1977 stipulates that the mayor has the obligation to protect historic monuments. The municipality was given responsibility to financially participate in the conservation of both public and private buildings in their municipal perimeters (Hamdan et al., 2012; Hanna, 2010).

\subsubsection{Conservation planning: an integral part of cities}

The shift in the conception of UHAs as an integral part of cities varies within our case-studies. In England, the 1967 Civic Amenities Act (updated in 1990) marked this transition by establishing conservation areas (CA) having 'special architectural or historic interest, the character or appearance of which is desirable to preserve or enhance' (UK Parliament, 1967, 1). This transition is closely tied to England's post-war demolition and rebuilding, which spurred many communities to take action. As we shall see this is reflected in the local nature of where power lies in the designation process.

Since their creation in 1967, CAs in England have evolved through different policy documents. Until recently, central government set the stage for the planning system through Planning Policy Statements and Guidance (PPG and PPS) (DCLG, 1994, 2010). PPG15 first laid out government policies for the identification and protection of historic buildings and conservation areas (DCLG, 1994). It explained how development and conservation generally needed to be considered together and broke down the links between the planning system and conservation policy (DCLG, 1994). It was replaced by PPS5, which highlighted planning's central role in conserving heritage assets in the perspective of using them in creating sustainable cities and preserving quality of life (DCLG, 2010). These policies, among others, were replaced in 2012 by the National Planning Policy Framework (NPPF) (DCLG, 2012). The NPPF sets out core principles that should underpin plan making, and includes the historic environment under the umbrella of the environmental role of the three dimensions of sustainable development (DCLG 2012, 2). It aimed at simplifying the national planning framework and was often described by 
interviewees as similar to the PPS5 but much less detailed. Whilst the borough policy officers we interviewed were concerned with the loss of detail between PPS5 and the NPPF there is striking evidence to suggest how powerful the heritage lobby was in securing a good outcome for conservation policy within the NPPF as the framework went through various stages of drafting (GLA2 and Historic England Interview) (Lennox, 2013).

In France, the legislative jump is not as clear-cut, the structure for the protection of UHAs has been characterised as a millefeuilles, a culinary metaphor that reflects the multiple (and many argue redundant) layers of regulation that result in numerous legislative tools protecting urban areas (Bleyon, 1981). Interviewees described it as extensive, binding and containing wide-ranging constrictive measures (STAP Paris Interview). The French attempt at solving this was the creation of the Code du Patrimoine in 2004, which brought together all the scattered texts on the protection of heritage (Code Du Patrimoine, 2010).

The 1943 act extended state control by establishing an easement to protect a $500 \mathrm{~m}$ perimeter around all historical monuments (Devernois et al., 2014). This measure is part of the heritage code and can be considered a French forerunner to the conservation area, but more importantly, it is a measure still implemented today. As emphasised by Planchet (2009), addressing the outskirts of historic buildings through an administrative constraint is far from linking monument legislation to town planning law. The technique strengthens the singularity of monuments and is based on the misleading assumption that conservation in the immediate vicinity of a monument remains bound to the historic monument (Choay, 1992; Le Louarn, 2011). None of our other northern examples apply such a restrictive measure. The concept of curtilage exists around listed buildings in England but, as recommended by Historic England, no line is ever drawn and the boundaries of the spatially protected area are up for interpretation (Historic England, 2015b). In fact, as written, the policy relating to curtilage and which structures may or may not be protected within it is rather vague and, like much of England's town planning regulation, has been further specified by case law rather than codification (Moore, 1987).

The 1943 law also restricts urban areas by adding sight line restrictions to the field of vision around the monument: within these areas any action changing the appearance of both buildings as outdoor spaces, cannot take place without the prior authorisation of the Architect of the Buildings of France (ABF) (Devernois et al., 2014). This role is one of the few remaining positions that permits individuals to hold sovereign power, a power superior to that of local mayors or prefects. This power is called the avis conforme and 
denotes the ABF's power to accept or decline any proposal to change or demolish buildings in curtailed areas around monuments (Art. 7. R425-18) (Devernois et al., 2014). Given the large number of historical monuments in France (about 40,000 across the country), this measure results in the ABF being in control of nearly 3 million hectares of land, which is roughly $5 \%$ of France (Ministère de la Culture et de la Communication, 2013). The law's most recent evolution (7 July 2016), finally limited the avis conforme ${ }^{5}$ to a smaller sector delimited around the monument by the ABF, leaving him with a avis simple in the rest of the area (Figure 3) (Ministère de la Culture et de la Communication, 2016). The reality of this amendment in the law is, however, as discussed with interviewees, that the state does not have the means to draw new individual specified perimeters for each of its 40,000 monuments (STAP Paris Interview). A coordination problem will thus arise between ABFs and local mayors, who will now need to take responsibility for all modifications in the newly created 'simplified sightlines' (avis simple areas). It is worth noting that a similar regulation exists in the UK context but applies only in London where specific sightlines are controlled to create viewing corridors to key monuments in the capital (GLA, 2012). The development of this policy, which has its origins in the London Building Act of 1894, helps to illustrate the importance of power, history and local development pressures to the creation of localised policy (for a fuller discussion see Historic England, 2018).

The French legislative system specifies an astonishing three other ways to designate UHAs. Secteurs Sauvegardés ${ }^{6}$ were introduced as an instrument in 1962 in a period in which heritage conservation was far from being at the top of the political agenda. Now part of the French urbanism code, they are part of the Plan de sauvegarde et de mise en valeur (PSMV) ${ }^{7}$ which replaces the local urban plan. With the decentralisation of the state in 1983 came the creation of protection zones for architectural and urban heritage and landscapes (ZPPAUP), now part of the heritage code (Cornu, 2003). Although the ZPPAUP aimed at designating UHAs, it did not entirely break from the pattern of protecting neighbourhoods around historic monuments. Although areas were now designated, they were not conceived as holistic landscapes in their own right but were an attempt to improve the 1943 law.

\footnotetext{
${ }^{5}$ The avis confrome is the French administrative action of giving assent and represents the irrefutable power to accept or decline any proposal to modify buildings. The avis simple is simply on the other hand closer to giving advice.

${ }^{6}$ Preserved sectors (Translated by the authors)

${ }^{7}$ Protection and enhancement plan (Translated by the authors)
} 
By 2010 policy evolved and the ZPPAUP were replaced by the aires de valorisation de l'architecture et du patrimoine (AVAP) ${ }^{8}$ (Code Du Patrimoine, 2010). The biggest marker of this evolution was the inclusion of concepts of well-being within a sustainable development framework. AVAP also required a management plan only partially subsidised by the state, which takes the form either of a Plan de Sauvegarde et de Mise en Valeur (PSMV) or of a heritage PLU (Rouillon, 2014). An attempt to simplify the urban heritage designation system was finally made in 2016 with a legislative amendment that regroups the secteurs sauvegardés, ZPPAUP and AVAP into one category: the Site Patrimoniales Remarquables $(S P R)^{9}$ (Ministère de la Culture et de la Communication, 2016). Although the details of the implementation of this most recent amendment to the legislation are still unclear, interviewees confirmed that if certain areas were prone to more than one UHAs legislation in the past, the most restrictive one would be applied (Ministry of Culture France Interviews).

Conservation planning has a unique place in the Italian context, so much so, that some have argued that the principles and practises of conservation planning are one of Italian urbanism's few contributions to the field (Balducci \& Gaeta, 2015). The Italian architect Gustavo Giovannoni coined the term 'urban heritage' in the 1930 s as obtaining its value not as an individual and autonomous object but as part of the overall character of urbanism (Choay, 1992). From 2004, all Italian public buildings constructed 70 or more years ago were automatically listed to avoid the loss of cultural values provided by civic architecture (Ministero dei beni culturali e delle attività culturali e del turismo, 2017).

Interestingly, the Italian system did not develop an UHAs designation strategy that resembles the English conservation areas or French ZPPAUP. The vincoli paesaggistico ${ }^{10}$ are derived solely from the 1939 environmental law mentioned earlier, which later received modifications in the 1980 s (n. 431/1985 "Aree tutelate per legge") and in 1999 (n. 490/99 'Testo Unico') (Ministero dei Beni e della Attività Culturali e del Turismo, 2016). The Cultural Heritage and Landscape code later (22 January 2004 n. 42) integrated these previous norms in an attempt to simplify legislation. Within this code, Article 136 and Article 142 apply to landscapes. Article 136 identifies buildings and areas of significant public interest ${ }^{11}$ while Article 142 identifies the areas having natural interest. Even though this construct is

\footnotetext{
${ }^{8}$ Areas of enhancement of architecture and heritage (Translated by the authors)

${ }^{9}$ Remarkable heritage sites (Translated by the authors)

${ }^{10}$ Landscape protection (Translated by the authors)

${ }^{11}$ These include a. good of specific administrative use b. 'immovable things', 'villas and gardens', 'parks' c. and d. 'complex of properties', 'areas of scenic beauty'
} 
tied initially to environmental rather than socio-cultural historical values, it includes restrictions linked to heritage more holistically. For Example, the neighbourhood of Brera, one of Milan's historic quarters, is protected by a vincoli paesaggistico and within its specifications it considers the preservation of its historic character by controlling things like the appearance and décor of buildings (MiBAC Interview) (Gazzetta Ufficiale, 2009). Therefore, even though this legislative feature does not classify the area as a culturally valuable one, it identifies it as being significant to people's identity and in so doing, as noted by our interviewees, the area's character and form can be protected through the imposition of measures to protect “... historicism, décor, view and perspective” (MiBAC and conservation legislation specialist Interviews).

What is distinctive about urban heritage 'creation' in Italy, however, is a considerable focus on the centro storico, both in policy and related literature (Albrecht \& Magrin, 2015; Morpugno, 2014) highlighting historic centre as retaining singular urban heritage value. Although this is true in other countries where UHAs are clustered in the centre of a city such as London (see Fig. 3) or Paris (see Fig. 4) through the Secteurs Sauvegardés, Italy not only institutionally defines these areas but specifically promotes them. ANCSA (Associazione Nazionale Centri Storici Artistici), founded in 1961 after the promulgation of the Gubbio charter, appealed the need to classify historical centres as a whole as unique examples of history where the phases of development could be clearly identified in light of a low number of modern replacements (Bonfantini 2015). ${ }^{12}$ The Commissione Franceschini in 1964 undertook a census of cultural property and underlined the value of the centri storici as settled urban structures that constitute cultural ensembles and the original and authentic part of settlements (Cosi, 2008; Olivetti et al., 2008). In fact, the concept of Italian historic centres was thought of as a way to preserve both the physical and social body of historic centres in order for these to remain interlinked (Albrecht \& Magrin, 2015). There is a clear distinction to be made between the vincoli paessagistici and historic centres. While the former presents elements both of valorisation and safeguarding, the latter are almost solely about promotion and valorisation (Art. 117, comma 3, of the Italian Constitution) (Fantini, 2014). In practice, many historic centres are partially superimposed by vincoli paessagistici (Figure 5).

The 1967 Legge Ponte (Law n. 765) officially included historic centres as part of overall city planning, delimiting them by the notation 'Zone A' in Italian Master plans or

\footnotetext{
${ }^{12}$ In many ways the conservation movement in Italy was in fact initiated by ANCSA. was originally animated by architects who's objective was to conserve the aesthetic value of historical centres.
} 
PRGs which delimits zoning areas, buildable exploitation and the areas to be allocated to public services (Campos-Venuti \& Oliva, 1993). ${ }^{13}$ Although this has evolved today, as historic centres are now defined on a case by case basis through their urban plans and with more complex zoning techniques, it underlines the significant value accorded to them in the Italian case. Various authors and interviewees (Politecnico Interview) (Bonfantini, 2012, 2013; Mioni \& Pedrazzini, 2005) stressed how historic centres are in no way replaceable, differing visually and perceptively from the rest of Italian settlements, because of their display of unmistakable patterns, underscoring the traits of strong spatial cohesion that is immediately morphologically recognisable. Italian conservation planning is thus emphasising historic centres' option value. Several interviewees stressed how the conception of Italian conservation planning is deeply seeded in the country's history and geography: the historic centre being a distinctive urban characteristic of the Italian urban landscape (UNESCO/ANCSA and CE Interview). Similar arguments could be made about certain historic centres in England or France, but they are not legislatively recognised in the same manner: in Italy, the temporal threshold is given much more weight.

The dangers of Italian historic centres are linked to the possible isolation and transformation of this central area, for in designating these central islands of land, there is a risk that the intangible values are gradually lost as they become areas for tourism and not for everyday people, referring back to the opposition of economic and intrinsic values as illustrated in Figure 1, which illustrates a fall away from the equilibrium point between economic value and intrinsic value when only one value is promoted. Although this is not the case in Milan, when the vincoli paesaggistici cover the whole of historic centres, the risk of this isolation happening is high (UNESCO/ANCSA and CLS Interviews). As Bandarin (2015) argues, there is no purpose in maintaining architectural appearance If you turn the city into an empty shell. Instead of going towards inclusiveness and the living nature of heritage, 'the historic centre creates insularisation' (Lombardy Region Interview) as a result of constraints tied to it and 'dangerously transforms the area into a theme park' (Italian historic centre specialist). This essentially describes the tipping point of the right-hand side of Figure 1, where the pursuit of this economic value (through tourism) begins to diminish the intrinsic value of UHAs through its consumption. It is important to again note variegation in the implementation and creation of policy even within countries. Here Milan, which is not only a cultural city but also a strong economic motor for Italy, has

\footnotetext{
${ }^{13}$ PRGs (Piano Regolatore Generale) are general regulatory plans for the city.
} 
applied the notion of vincoli paesaggistici in a slightly different way that allows for the valuation of heritage but also ensures places for economic development.

Similar to the French and Italian systems, Brazil inserted conservation within its zoning policies. Brazilian zoning delimited areas of historic, artistic or environmental value (Afonso da Silva, 1968). Law 3.289/1983 created zoning for the protection of urban areas of cultural or landscape value and demarcated them as undevelopable. Law 10.829/1987 outlined that all urban master plans should have four zones. Similar to Italian historic centres, the monumental zone should feature the main characteristics of the city's urban design (F. F. da Silva, 2012), however, it does not receive as much attention in the literature. In fact, architectural and planning movements in Brazil have often been overlooked despite featuring planning protagonists such as Lucio Costa or Roberto Burle Marx.

The shift in the conception of UHA's in Brazil had indeed been successful. Article 215 and 216 of the Brazilian Constitution of 1988 departed from the use of the word monument to refer to 'urban complexes and sites manifesting artistic-cultural value' (F. F. da Silva, 2012). It also expanded the definition of value by stating that heritage is all things 'bearing reference to identity, action, memory of Brazilian society' (Batista \& Macedo, 2010). It further designated all sites retaining historic references to quilombos communities (slaves) (F. F. da Silva, 2012), reflecting the incorporation of diversity into the values that underpin conservation in Brazil (PROURB Interview). The 1988 Constitution also laid the groundwork for the 2001 evolution of conservation planning. Although Brazil does not place urban heritage within the remit of environmental, as does Italy and France, Article 225 of the 1988 Constitution underlined the right of everyone to an ecologically balanced environment, requiring federal entities or municipalities to include environmental analysis in their creation of conservation areas (Castriota, 2008).

The $10.237 / 2001$ Estatuto da Cidade - City Statute law builds on the 1988 Constitution to create a new legal urban order to provide land access and equity in large urban cities. The main concept behind many of the instruments of the City Statute is that all property has a social function and in that manner, land is seen as much as a public good as a marketable one, recognizing the existence and bequest values of areas (R. C. M. Da Silva, 2012; F. F. da Silva, 2012). Special Interest Districts (SID) can be registered within this law with different foci: social, environmental, cultural or functional. Cultural Special Districts are most often the ones more closely tied to urban heritage, and include specifications of the types of preservation for each building within them (R. C. M. Da Silva, 2012). Districts inscribed for cultural values are known as APAC in the city of Rio de Janeiro and are most 
often established by the Rio General Department of Cultural Heritage (DGPC) which is part of the Municipal Secretary of Cultures (R. C. M. Da Silva, 2012). Article 123 of the City Statute specifies that urban areas can also be inscribed for their environmental value, for example, in Rio de Janeiro, green areas play an important role in the memory and identity of the city (see Fig. (Batista \& Macedo, 2010). Article 123 therefore promotes and respects locally derived values of preservation.

Although our southern case-studies present similarities, while historical zoning was incorporated in many city plans in Brazil, the zoning of Lebanon today covers only $16 \%$ of the territory (UN-Habitat, 2011). The non-regulated parts are entirely developable, and policies applied to regulated sections are commonly disregarded (whether addressing conservation or other urban concerns) (CDR Interview) (Tyan, 2012). This lack of regulation gives way to high exploitation coefficients (cost of regulation vs profit via development), parcel amalgamation and the construction of large highways through historic urban areas (SBH and APLH Interviews). Beirut's Master Plan has not been updated since 1964, and most efforts to amend it or to introduce a new Master Plan have been hindered by political pressure (Ashkar, 2018). Examples of municipalities who conceptualise urban heritage's touristic economic potential are rare (Akl \& Davie, 1999).

During the Lebanese civil war (1975-1990) the centre of Beirut was gravely damaged. Many buildings, such as those constructed under the French mandate, were perceived as symbols of a blamed political order rather than as part of the nation's identity and were the target of hostile factions (Tabet, 2001). Beirut as a whole, however, maintained a certain coherence, with only an estimated $10 \%$ of buildings destroyed (Tabet, 2001). It is in fact often argued that although the destruction of Lebanon's urban heritage began during the war, it only really boomed during its reconstruction (Akl \& Davie, 1999; Davie, 2001, 2004). This is in contrast to Europe, where the urban destruction of the Second World War led to the development of modern town planning with conservation as part of the conversation, suggesting different outcomes for conservation planning depending on the nature of war (civil or between nations). This echoes the work of Bevir and Rhodes $(2006,89)$ who note how inherited traditions can be disrupted by crises of identity making it difficult to formalise these values.

The shift in the conception of UHAs as an integral part of cities was attempted after the war with little successes. It was not until 2008 that a new law was established to enlarge the conservation of urban fabric (Hanna, 2010). This legislative project was led by Ghassan Salamé, Minister of Culture (2000-2003) with the aim of recognising the notion of 
architectural value and urban ensemble to be protected (LOCE and UNESCO-LB Interviews). Article 2 of the 2008 N.37 law on cultural goods enlarged the heritage sector to cover urban fabric, it recognised the 'historical, scientific, aesthetic, architectural or symbolic value, whether religious or secular' of many immoveable properties including 'structures, landmarks, edifices, buildings, or part thereof' (International Foundation for Art Research (IFAR), 2014). Although a more inclusive definition of urban heritage was now ratified, underlining the different intrinsic values of immoveable objects, bylaws were never issued to provide a framework for its operation and management (SBH Interview). As yet no precedent has been set for its application, making it very difficult to be used to protect UHAs. This is one of many examples that characterises the evolution of conservation planning in Lebanon, although societal desires are present, as seen in NGO activism (SBH and APLH interviews), political will is rare, and most often lacks follow through mainly because of the aggressiveness of real estate as Lebanon's biggest economic driver (Hanna, 2010; Krijnen, 2010; Krijnen \& Fawaz, 2010).

In Lebanon other attempts were made to further conservation at a city level. In 1995 in Lebanon, the Council for Development and Reconstruction (CDR), ${ }^{14}$ inventoried 1,016 houses built between 1860 and 1943 in the peri-central area of Beirut and proposed classification (Tyan, 2012). The list formed the first reference of a census of heritage buildings in Beirut, and the basis on which the Ministry of Culture requested the Governor of the city to take temporary measures to freeze demolition. This measure led to a massive campaign organised by the owners, in which they demanded that the state either overturn its decision or provide compensation for the injustice and subsequent economic damage caused by the freeze (CDR Interview) (Akl \& Davie, 1999). Giving way to socio-political pressure, and the values of private property, the CDR restricted the inventory, whereby 592 properties were freed from registration and only 459 buildings divided into five categories (A, B, C, D \& E) remained (Resolution No. 97/12 on 2/6/1997). In 1999, after continuing pressure, $\mathrm{D}$ and $\mathrm{E}$ were also eliminated from the list by official decree (No. 32 on 3/3/1999).

This was done by claiming that the buildings lacked a cultural component, thus limiting urban heritage's definition and thereby its embedded value to a cultural one (Council of Ministers Lebanese Republic, 2010). A decree was also later signed that closed this inventory, meaning that no institutional entity could add buildings to be protected

\footnotetext{
${ }^{14}$ At the request of the Minister of Culture Michel Eddé and with the assistance of the Lebanese Association for the Protection of Sites and Historic Monuments (APSAD).
} 
(SBH and APLH Interviews). In 2010, the Council of Ministers commissioned the CDR to conduct a comprehensive study of the buildings under frozen demolition, recommending the release of buildings not having a cultural component. This progression reflected negatively on the unity of the few remaining traditional neighbourhoods in the city of Beirut. As interviewees lamented (CDR, UNESCO-LB, SBH Interviews), in Beirut, conservation planning never really took on a broader scope and has mostly failed in recognizing the value of urban heritage fabric, with some successes for isolated buildings.

It is clear from this analysis of the evolution of urban heritage legislation in our five case-studies that context plays a substantial role in how urban heritage is 'created'. Even though the beginning of conservation planning is very similar between all our examples, planning cultures and the contingent histories of place influence national definitions of urban heritage, meaning that these built forms are somehow valued differently.

\subsection{From cultural to holistic non-use values}

As we have seen in the previous section, the reasons behind why monuments and UHAs are designated is tied to different types of value associated with these different heritage forms. While single heritage designations appear to be tied to historic and cultural values, UHAs are first conceived from an environmental value perspective in Italy (vincoli paesaggistici) and France (sites inscrits), from the perspective of cultural-historical value in England, to a cultural or landscape value perspective in Brazil. These initial values, however, have evolved both through the conceptual evolution of these first designations and also through the creation of new regulatory tools.

Our review of multiple policy documents for this paper suggests that the policy trend altered from being concerned primarily with cultural and historic urban heritage values to having a more holistic understanding of what urban heritage might be in four of our case-studies. The joint consideration of socio-cultural, historical, environmental, and economic values becomes predominant and inscribes heritage into the sustainable development discourse (Council of European Union, 2014; Gayego, 2014; Vernieres et al., 2012). This suggests at least a partial incorporation of urban heritage values as understood through TEV delineation into national policies.

In England, the NPPF is now the key document linking urban heritage to sustainability. It highlights 'the wider social, cultural, economic and environmental benefits that conservation of the historic environment can bring' (DCLG, 2012, 126). It also states that local planning authorities should take into account the positive contribution that conservation of heritage assets can make to sustainable communities including their economic vitality (DCLG, 2012, 131), clearly appealing to both use and non-use values of 
urban heritage. The NPPF also included the historic environment under the environmental umbrella within the three dimensions of sustainable development, associating urban heritage with environmental values when initially conservation areas were underpinned and valued for their historical and architectural interests (DCLG 2012, 2). This illustrates the evolution of heritage policy in England, which has, over the years been able to shift itself with the leitmotif of the day going from the promotion of conservation for its own sake, to the promotion of heritage based on its value as a tool for economic and placed based regeneration to now as a promoter of sustainable growth.

In France, the biggest change in the evolution of urban heritage came with the progression from the ZPPAUP to the AVAP in 2010. The Loi de Grenelle (2010) introduced sustainable development notions through the AVAP that were not previously present, establishing a national engagement to the environment and altering the underlining values of UHAs in France (ICOMOS France, 2010). The AVAP also included well-being into its conceptualisation, introducing the notion that the value of UHAs is linked to urban emotional perceptions (Code Du Patrimoine, 2010). The evolutions in English and French conservation planning thus present similarities in repositioning themselves closer to discourses of sustainability and emphasizing the multidimensionality of values. It seems governments were keen to streamline conservation planning by linking it to sustainability and making it part of a more popular and accessible discourse.

In Italy, the theoretical jump in legislation is less specified but still present. Art 143 of the updated Cultural Heritage and Landscape code mentions the necessity to find 'correct ways to insert modern elements in landscape areas' in order to 'sustainably develop these areas' (Carughi, 2012). Moreover, although the historic centre is a concept linked to the history of a given city, it has been argued that it also supports notions of sustainability through its links to the UNESCO 2011 Recommendations on the historic urban landscape (Bonfantini, 2015). Therefore, although Italian conservation planning doesn't specify sustainability's role in related legislative documents, or in practice, as commented by one of our interviewees (CLS Interview) it has subtly attempted to include it within the conservation discourse.

Although Lebanese legislation remains vague, specifying solely historic and artistic values, its Brazilian counterpart includes all the modern values at very early stages of urban heritage conservation, acknowledging economic, cultural, historic and natural values (Dalmas et al., 2015). As Canani (2005) explains the 25/1937 law specifies that when verifying each building or monument, it is necessary to question what values it represents, 
which attributes justify its existence, and what kind of relationship it fosters with the local people, thus addressing the existence, bequest and option values of urban heritage. The 25/37 Law has been commended by many (Batista \& Macedo, 2010; F. F. da Silva, 2012). Despite its age, its concepts, regulations and purpose are clear, remaining relevant even now.

These evolutions or original multi-dimensionalities of value as in the Brazilian case suggest two things. First that the international push to include urban heritage into the sustainable cities discourse was successful given that national policies rephrased urban heritage in this perspective. Agenda 21 for Culture's Fourth Pillar of Sustainable Development (by United Cities and Local Governments) exemplifies this movement, followed by the inclusion of heritage in the sustainable cities discourse of the Sustainable Development Goals (SDG) and its inclusion in the recent United Nations Conference on Housing and Sustainable Urban Development (Habitat III 2015; UCLG 2005). The evolution of conservation planning in our case-studies suggests that the concepts of these movements have effectively trickled down to national policies.

Secondly, it can be argued that as conservation is a 'luxury' of planning, its inclusion into a sustainability discourse might therefore have been orchestrated to give it more gravitas, not unlike earlier shifts toward more economic language. The restoration and maintenance of urban heritage is often considered an expenditure of resources that could better be used in other ways. Conservation is thus intricately tied with the cost of an alternative that must be forgone in order to preserve heritage buildings (Provins et al., 2005; Serageldin, 1999; Tuan \& Navrud, 2007). If a high proportion of a city's economy is linked to construction and/or real-estate development, net income sacrificed to conservation will be high and cities in urgent need of economic growth will not be willing to make the sacrifice (Barton et al., 2013). This is especially true in places where weak governance systems do not enforce planning as we shall see in the second part of this paper. We cannot forget that there is often a prevalent political rhetoric favouring economic maximisation over other social constructions of value, which occurs in both the Global North and the Global South (Ahlfeldt \& Holman, 2015; R. Lee, 2011).

Perhaps in order to overcome this rhetoric, conservation has often gained importance not as a cultural variable within planning but as one inserted into the sustainable development discourse, thus attracting more attention by modifying how it is included in policy. This could also be why heritage is often classified as an urban amenity, as a way of boosting attractiveness (Finco \& Nijkamp, 2001; Glaeser et al., 2001). Even 
organisms like UNESCO have somehow compromised, adjusting their interpretations of historic landscapes to be much more inclusive, to use the words of Bandarin $(2015,14)$ a 'much more flexible, open-ended and people driven approach to conservation'.

\section{Heritage in Space}

\subsection{Heritage Counts}

Spatially we see the regulations impacting on our case study cities in the various ways. Listed buildings in both London $(16,420)$ and Paris $(3,842)$ are great in number and were designated over an extended period of time going back as far as the 1850 s. Milan counts 1677 listed buildings however data on their year of designations is unfortunately not readily available. UHAs in Paris (22) and Milan (31) only reach a maximum of 6 designated areas a year, while London (965) sees high number of designations from the 1970s. However, despite London's large number of UHAs this does not mean that London in necessarily more constrained than Paris. Not only are UHAs in Paris more spatially extensive, English CA policy can, in many cases, be less restrictive given it is locally arbitrated and locally enforced.

Lebanon's attempts at classifying historic buildings is very sporadic, with only 37 monuments and architectural elements classified through decree on the General Inventory of Historical Monuments between 1934 and 2002, and 1,367 listed through orders for the entire country (DGA Interview) (Toubekias \& Dentzer, 2009). Data on the number of nationally listed buildings in Beirut is unavailable and just over 200 buildings from categories A, B, C of Resolution No. 97/12 on 2/6/1997 have escaped demolition (APLH Interview). There are no formally inscribed UHA's areas in Beirut, a few streets were identified as part of the only real attempt to further UHA legislation in the 1990s, but the only result was the Municipality's marking of roads in question with signs saying 'Rue à caractère traditionnel' (road with traditional character). Rio de Janeiro on the other hand, presents numbers much closer to our European examples. The General Department of Cultural Heritages (DGPC), part of the Municipal Secretary of Cultures, is Responsible for preservation of over 2,000 listed buildings (bens tombados), 10,000 minor listed buildings (bens preservados), and over 90 UHAs (APAC), numbers close to the amount of listed buildings in London (IRPH, 2018). 


\subsection{UHAs as a spatial construct}

Figures 2, 3 and 4 demonstrate how the size of UHAs and the details of their spatial demarcations vary in light of the evolution of legislations discussed above. CAs in England are relatively small, delimited areas, they usually do not map full city centres but several, even many specific areas within them. In large cities, such as London, they are clustered in the centre of the city, marking its most historic part despite the absence of other regulations, with the exception of strategic protected views in London, which are designated by the Mayor. These strategic views are focused on St Paul's Cathedral, the Palace of Westminster and the Tower of London and are broken into the categories of: Panorama; River Prospects and Townscape. In practice, these views are protected from development that may obscure them. This does not mean that new development is not possible, only that any development should be sensitive to these sightlines. Historical centres usually count several CA's such as a range of houses or a square and its surrounding buildings. The delimitations are particularly specific, presenting an attempted reconciliation between conservation planning and mainstream modern town planning. They allow construction of new builds both within and between them and they are not integrated into local urban plans (Rodwell 2007). Some areas like South West London do have contiguous CAs that create larger designated areas, but these are locally controlled and managed meaning that the rigidity of policy is, to some extent, locally varied.

Fig. 2 London 


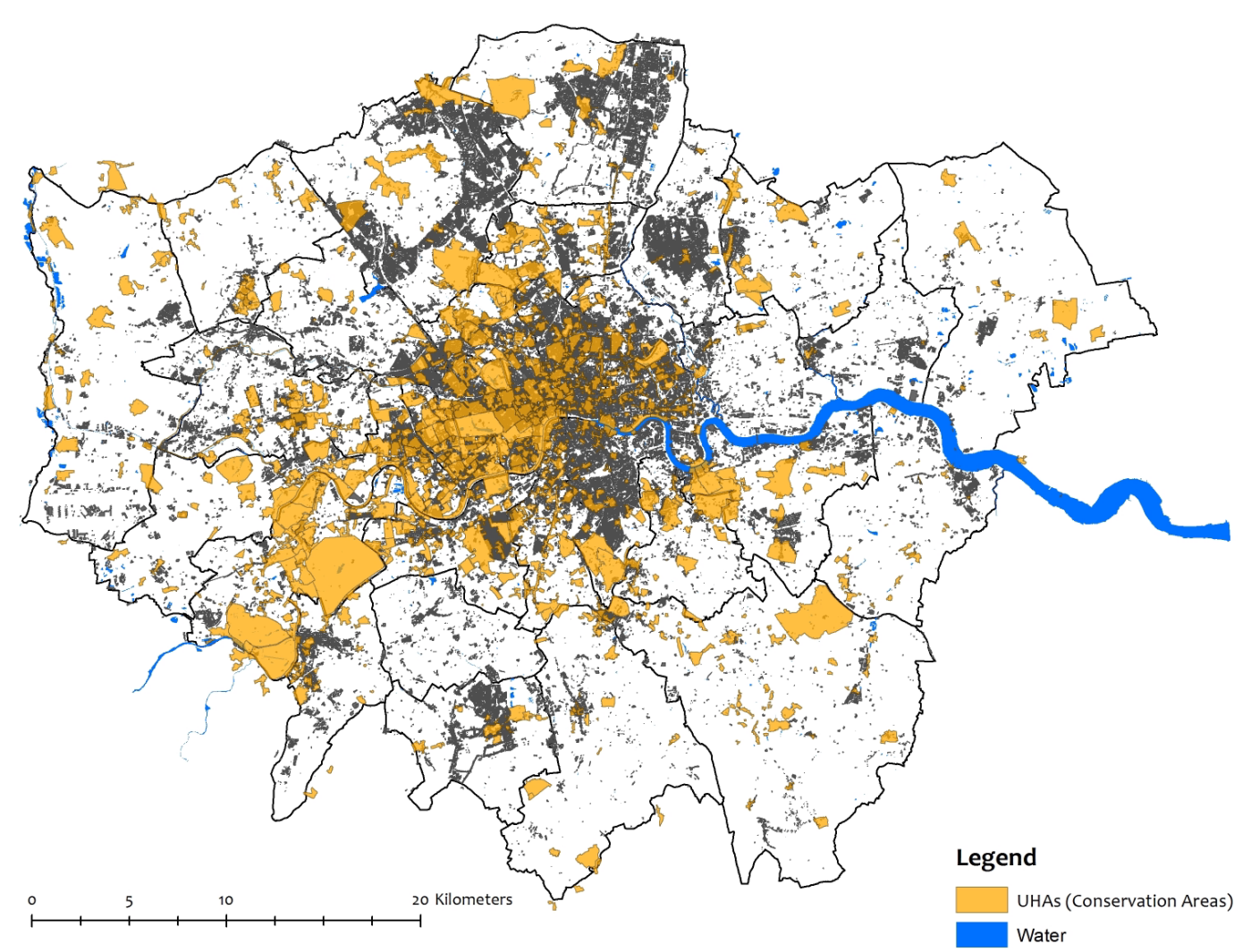

The superposition of French conservation areas results in $93,5 \%$ of Paris being subject to some form of regulation. The Secteurs Sauvgardés are typically neighbourhoods, in Paris the $7^{\text {th }}$ arrondissement and the Marais. What used to be the SPR range from the size of small neighbourhood to half a city. None are found in Paris itself but there are over 40 in the lle-de-France area, many of which are show in the 'Grand Paris' areas in Figure 4. Paris not only has an extensive site inscrit, as mentioned earlier, it also has a series of sites classes which include all the parks in Paris as well as some of the most important perspectives in the city such as the Invalides esplanade. When asked why Paris does not have ZPPAUP/AVAP, interviewees responded that the wide range of conservation planning present within the inner walls of Paris made it unnecessary (STAP Ile-de-France Interview). In fact, throughout the whole site inscrit the ABF has an avis confome on all demolition. Moreover, the layering of 2000 historic monuments, an inscribed site, and two secteurs sauvegardés and various smaller site classes means that there is very little that needs further conservation. As an interviewee said: there are 2150 conservation constraints on 1950 buildings (Paris Municipality Interview). 


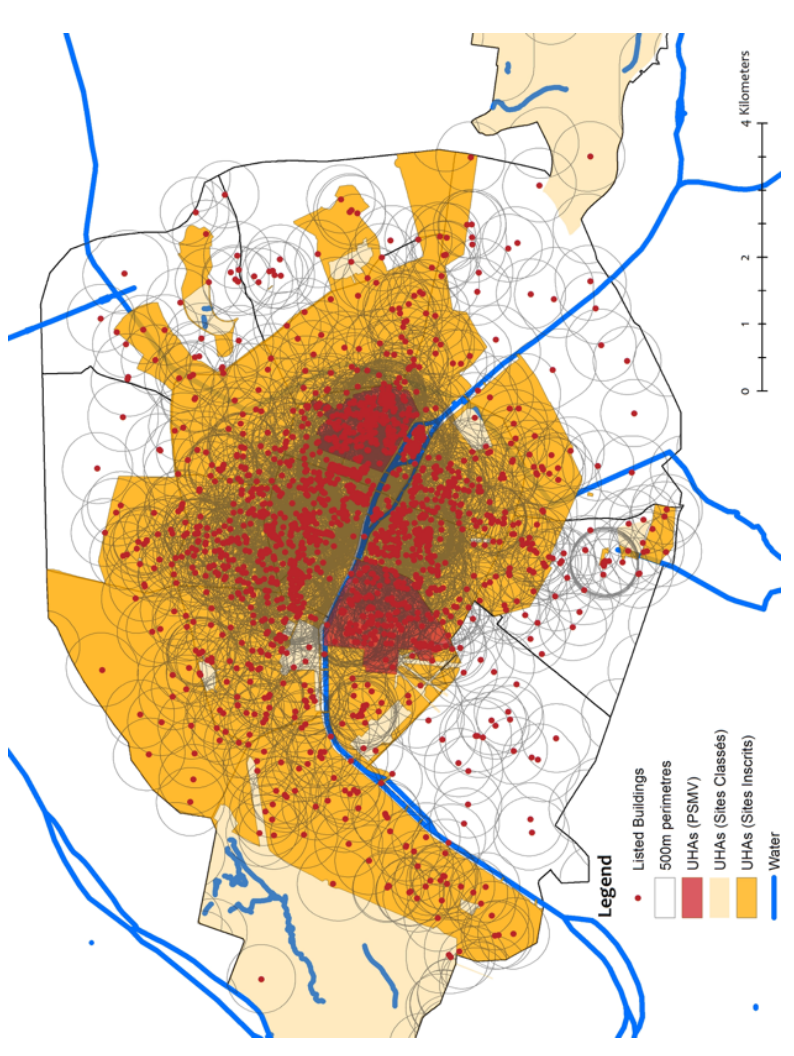


Fig. 4 Milan

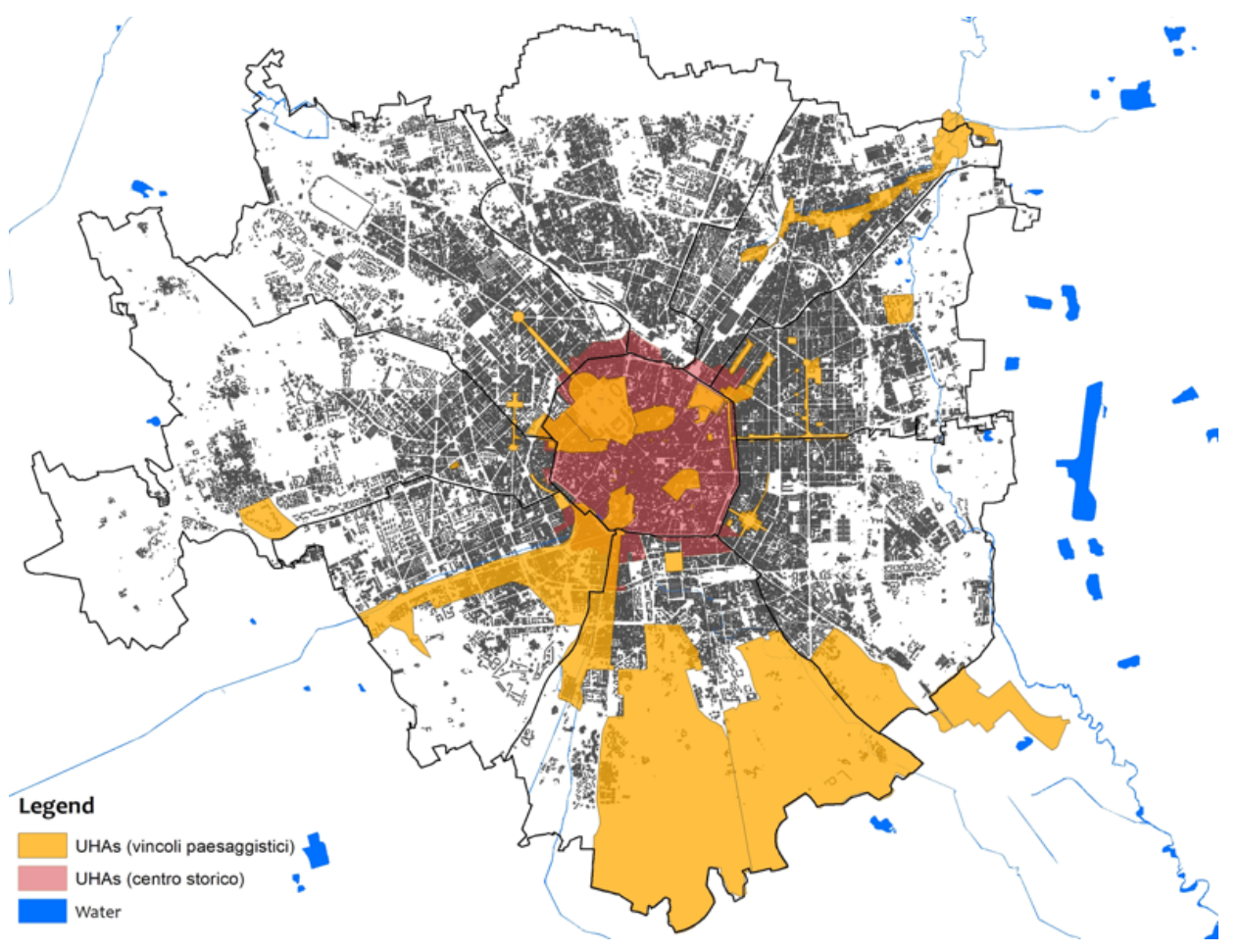

Vincoli paesaggistici have similar spatial delimitations to English conservation areas.

For example, Milan has 31 vincoli paessagistici including the neighbourhood of Brera, the area around the Castello Sforzesco and the area di via Francesco Sforza e Largo Richini. The greatest difference in the Italian demarcation of urban heritage can be observed through the historic centre. It is characterised by its insularity, which is quite striking as we can see in Figure 5 (Bonfantini 2013). This has led, in recent urban plans, to the transition from the notion of historic centre to that of historic city as colourfully argued by Bonfantini $(2012,2)$. The difficulty arises, however, with the recognition of the historic environment, which is not part of the historic centre in a given context. Conservation planning cannot simply equate to the widening of cartographic boundaries of a historic centre based on the extension of a temporal threshold as has sometimes been done (Bonfantini 2012). In Naples the local authority (LA) decided to extend the historic centre perimeter from the 19th century to the early 2oth century, bringing the historic centre beyond its traditional definition or pre-industrial urban fabric (Argan 1990). The danger of this simple extension is the creation of static museum cities, which have been highly criticised by heritage specialists (Bandarin, 2015; Bonfantini, 2012).

Figures 6 and 7 demonstrate the great differences in size and extent of UHAs in Beirut and Rio de Janeiro determined by the evolution of legislation. APACs in Rio de Janeiro are concentrated in the Central and Southern districts of the city, with a few 
recently inscribed in suburban neighbourhoods such as the APAC de Marechal Hermes $\left(\mathrm{N}^{\circ}\right.$ 37.069/2013) (IRPH, 2018). UHAs range from small delimited areas, similar to London, to much larger areas such as the APAC of Santa Teresa (L.495 - 09/01/1984 N 5.050/1985), which not only covers Rio's Montmartre typical $19^{\text {th }}$ century and belle-époque buildings, but also part of the mountain going up to Cristo Redentor (IRPH, 2018). Part of the Santa Teresa APAC was also inscribed as a Cultural Landscape on the World Heritage List in 2012 (UNESCO, 2012). In the central areas of the city, many of the APAC have contiguous borders, resulting in larger designated areas, for example the Corredor Cultural neighbours the Cruz Vermelha APAC and the Arcos de Lapa (Borde \& Sampaio, 2012). Unlike our European case-studies (with the exception to some extent of England and the mezzogiorno in Italy), despite the considerable spatial extent of UHAs within Rio, the enforcement of the regulation varies greatly, this often depends on the local population's support of the preservation of their neighbourhood and is not helped by the lack of management plans for any of the Rio UHAs (PROURB and Rio Municipality interviews).

Fig. 5 Rio de Janeiro

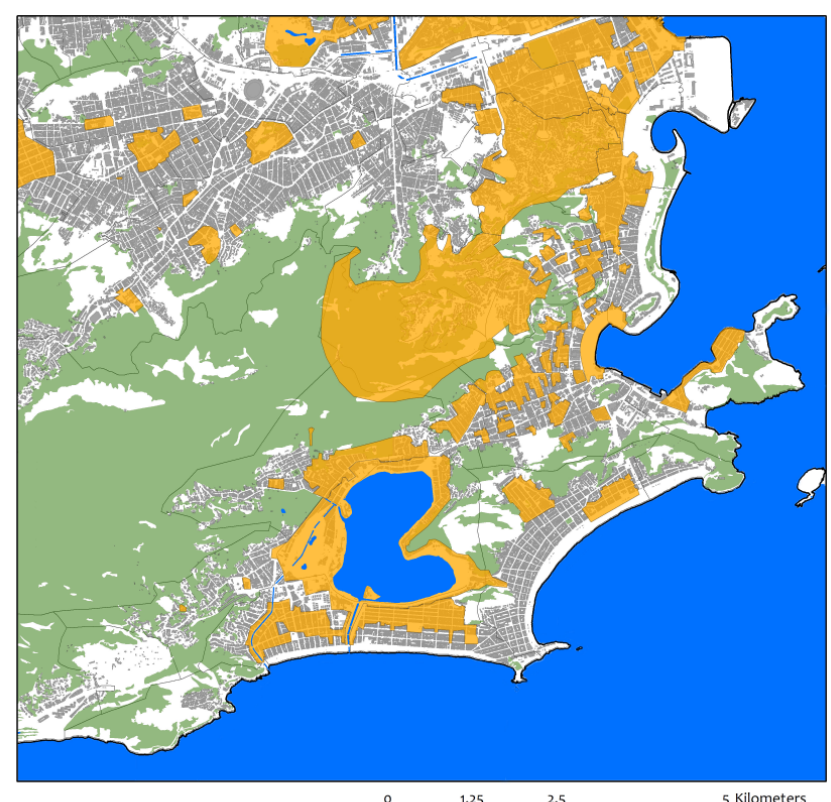

Legend
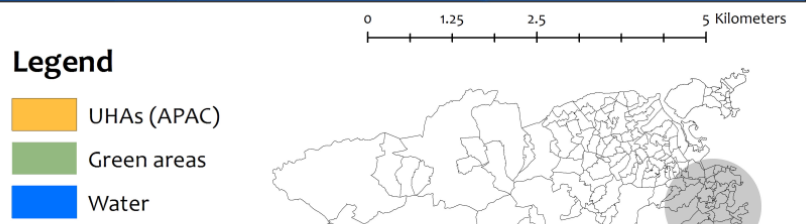

Note: Data from Prefeitura do Rio de Janeiro

Between all our case studies, Beirut presents the weakest example in terms of the spatial extent of its conservation planning. As illustrated in Figure 7, of the individual 
buildings locally listed in 1997 (Resolution No. 97/12 on 2/6/1997) few remained in 2009 and even fewer today (Pietrostefani, 2015). The UHA clearly identified around these clusters of heritage buildings are marked by signs denoting 'roads with traditional character' but remain mostly as nostalgic reminders of a historic urban fabric which is no longer intact, and their protection is in no way enforced (CDR and APLH Interviews). We thus observe evident differences in the spatial demarcations of UHAs in our two southern examples. While UHAs in Rio are well-defined and spatially extensive, in Beirut although an effort at defining UHAs was attempted, its formalisation through legislation was not followedthrough. Heritage is morphologically valued differently in Beirut and Rio.

Fig. 6 Beirut

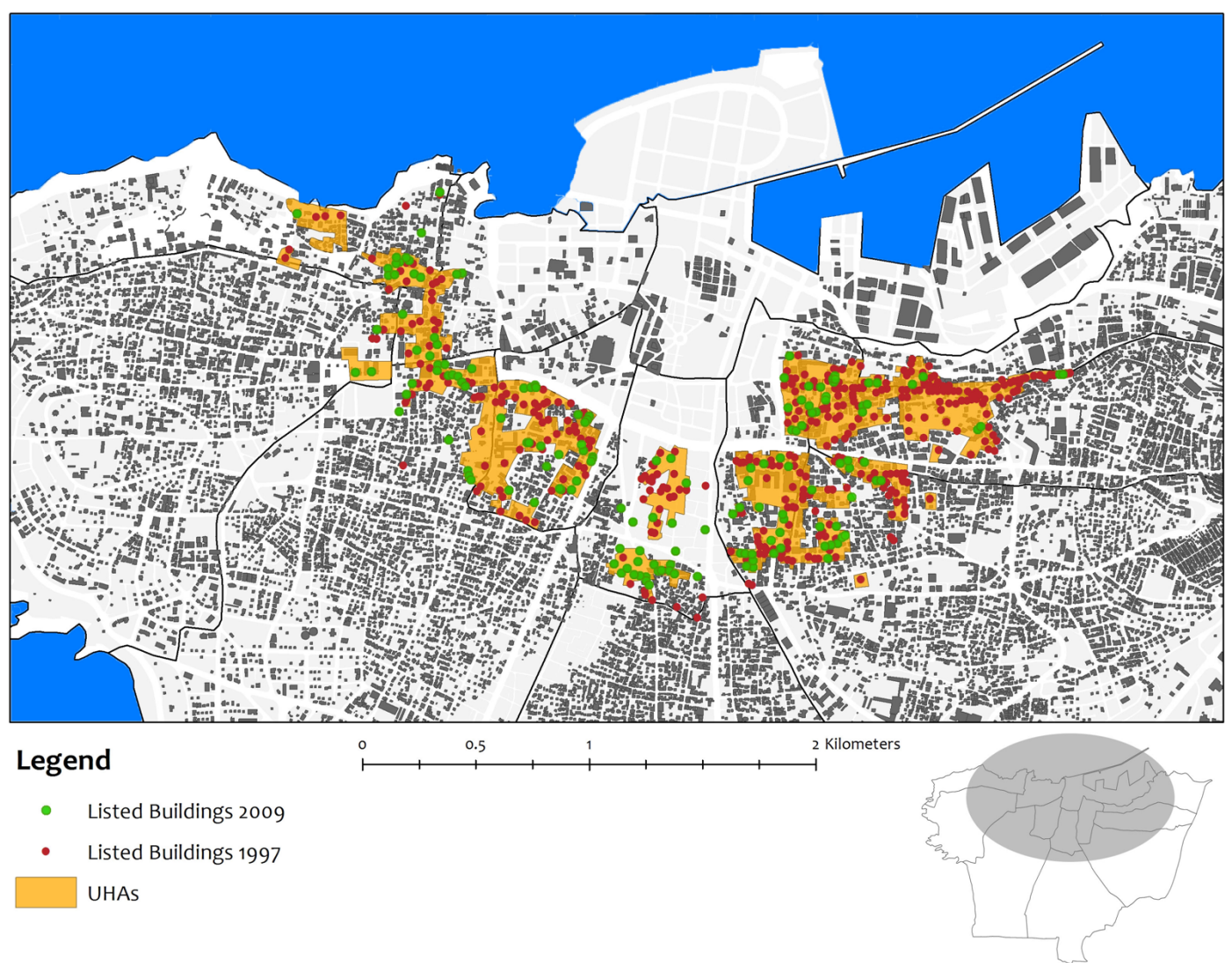

Note: Data from Majal - Academic Urban Observatory. Academie Libanaise des Beaux Arts. Red points mark buildings identified and listed in 1997 that are now demolished. Green points mark buildings identified and listed in 1997 that were still existing in 2009, few of which still remain today.

Our case-studies show that urban fabrics are valued differently according to geographical context and suggest that policies need to be interpreted within their own context and not through policy transfer. Our hyper-factual approach has helped us demonstrate that heritage is morphologically valued differently in London, Paris, Milan, Rio and Beirut (Ridley in Rhodes 1997), although similarities are present, such as the spatial concentration of 
value in the most central, typically most historic areas of each of these cities. While historic centres and large neighbourhoods are valued in Milan and Rio, smaller concentrated UHAs allowing for greater building flexibility are appreciated in London and numerous layers of conservation systems are applied in Paris resulting in almost no flexibility. Upon reflection, not only are these differences observable to the naked eye in these cities, but they result in some urban fabrics being more coherent that others in light of the dissimilar spatial protections. This suggests that although the planning system is not the only element that will determine heritage value, it will implicitly change how urban heritage is viewed by the population. Valuing urban heritage is therefore necessarily rooted in the analysis of country planning systems where zoning plays a major role as it results in different integrations of urban heritage in the city.

It is clear that there is not one way of defining and thus 'creating' UHAs even between countries with similar planning origins such as France and Italy. Urban heritage is engrained in local history both conceptually and spatially and this inevitably modifies its construction within planning. As such, heritage is a social construction dependent upon spatial and temporal interpretations of the past: this implies that its meaning is likely to change through time and across space, adding to its complexity.

In practice, however, spatial identification presents limitations. Despite different evolutions of conservation between Rio and Beirut, for example, as we shall see in section 4.4 , the planning issues at stake present many parallels. In Rio, even though spatially conservation is extensive, in practice regulation is not necessarily respected and conservation of heritage buildings is in many cases more closely tied to local will and realestate pressure than legislative presence (PROURB Interview). Borde \& Sampaio (2012) observe discontinuity within the Rio's urban fabric, typified by significant morphological contrasts: narrow lanes of the original neighbourhoods cut by wide avenues of the twentieth century; heritage houses preserved as a backdrop of recent skyscrapers driven by densification (Guimaraens, 2002); urban voids and buildings in an accelerated state of degradation driven by the densification of the centre of Rio (Guimaraens, 2002). The extensive legislative mapping is thus not necessarily what can be observed with the naked eye in certain contexts and is not necessarily representative of conservation planning in practice, highlighting the paradoxes of the Carioca urban planning process. Similar tensions are also wide-spread in Beirut. 


\section{Reflections on intrinsic vs. economic values}

\subsection{The role of public officials}

The extent of the constraints these various conservation planning systems present, together with the degree to which they are enforced, also speaks to how urban heritage is valued within a given context. The principal actors defining and enforcing the systems are necessarily involved. Values alter depending on the level of government deciding heritage constructs, shapes and restrictions. In other words, who decides what is valuable? Does the mayor, the local authority, the residents or central government decide? And if different actors are involved does this lead to coordination problems? As argued by Rhodes (2007), not only do patterned, interdependent, and bargained behaviours of government vary between contexts but so does their configuration, building different policy networks.

The English system must be applauded for making this negotiation local. The NPPF eliminated the regional planning apparatus (except for London) and introduced neighbourhood planning providing, a set of tools for local people to ensure the developments in their areas reflect community motivations (Paragraph. 184 DCLG 2012). LPAs are responsible for the designation and supervision of CAs, making urban heritage designation in England a locally defined system. If urban heritage is ultimately for people, especially those who live in and around an UHA, power residing with local governments seems appropriate. In fact, criteria for selection of CAs varies from region to region, making the value attached to heritage interpreted through specific sites and places (Lee, 2006). The designation process in England thus reflects the interests of local society; locally defined places are then provided protection under national planning legislation (Ahlfeldt \& Holman, 2015, p. 174). This underlines the complexities of valuing urban heritage across one country, and touches on the complexities of values that will arise in analysing examples from wide-ranging contexts in this paper (Pendlebury, 2009). In fact, interviewees who dealt with heritage at a national level found it difficult to generalise what aspects of CAs were valued with many local choices viewed as peculiar or unexpected in terms of designation (Historic England Interview).

In practice, LPAs have only limited resources in terms of enforcement and typically the system is reactive rather than proactive with officers only checking work where complaints are made (Harris, 2013). This makes CA integrity incredibly reliant on collaboration between communities and local planners (Ahlfeldt \& Holman, 2015). Interviewees commented that the control of conservation areas is not what it should be 
(GLA 1 and Hackney Borough Interviews). The loss of front gardens, replacement of windows and doors are a common feature when private houses do not demolish but radically change a building's appearance without asking for permission. Interviewees commented that this ties to a political idea in England that an individual's house is their castle, and therefore unless the CA has an Article 4 Directive (a legal proviso, which extends and strengthens planning control) the council is not able to enforce higher standards. LPAs have the right to withdraw permitted developments under Article 4 directives, which compromised in 2009 about 13\% of all CAs in England (Ahlfeldt \& Holman, 2015). This demonstrates the inherent role LPAs have in the protection, or not, of UHAs and illustrates how local attitudes and values act as support within the process. In France, the opposite was noted by interviewees: owners might lay claim to the right to dispose of their good as they see fit but the concept of public good is so engrained in the law and in society that the 'existence value' of the heritage for the public will almost always succeed (STAP Paris Interview).

As discussed earlier in this paper, French conservation planning is characterised by heavy restrictions and the layering and juxtaposition of legislation, resulting in a building often being subject to more than one regulation. It is difficult to ascertain where heritage 'creation' lies in French conservation planning. Each of the multiple UHA designations is tied to an authority. Listed buildings are linked to the conservateurs des monuments historiques; what were the 500m perimeters, the ZPPAUP and secteurs sauvegardés, are the responsibility of the Architect of the Buildings of France (ABFs); while the management of the sites is a matter handled by the Minister of the Environment. The ABF's power certainly encompasses the most land. In Paris the ABF holds absolute planning control over $90 \%$ of the territory as well as an avis simple for all building permits and urban planning certificates etc. This power denotes the importance of history in the conception of conservation planning, for it comes out of a post-war concern to preserve areas that had not been damaged during the war (STAP Ile-de-France Interview). As an interviewee noted, such a measure would never be allowed today, as it evokes regal institutionalism, but remains as a result of history (STAP Paris Interview). In some ways, therefore, the French conservation planning system has opted to 'maintain such power with heritage experts and (make it in a way undemocratic) to protect it' (STAP lle-de-France Interview).

Restrictions in Italy vary whether a building is public or private. When the building is private there is an obligation to conserve it and the soprintendenza - the regional cultural heritage authority - can impose works to be carried out on buildings (Ministero dei Beni e 
le Attività Culturali, 2016). The restrictions and confinements of vincoli paesaggistici are not much less invasive (Politecnico Interview). The vincoli paesaggistici are nominated by the region, who identifies and starts the designation process, establishes specific guidelines which are then delegated to municipalities after the approval of the sopraintendeze. Restrictions are detailed in the plan and are controlled by regional government. Just like the French system is characterised by the power held by the ABF, the Italian system is characterised by the role of the soprintendenza. This body decides all detail related to vincoli architettonici and buildings surrounding them in an ad-hoc perimeter. In practice, they decide many elements of the décor of urban areas, vastly limiting the freedom to build or modify in designated areas. These include binding procedures related to building work, with restoration only carried out by qualified staff - disputes have arisen between the state and the region on the training such staff should have received (MiBAC interview).

Despite the advancement of conservation planning in Brazil, a series of institutional and economic complications make its implementation difficult. Castriota (2008) argues a disarticulation of the various bodies responsible for the preservation and administration of Brazilian cities. In the case of Rio, the federal (IPHAN), state (INEPAC (State Institute of Cultural Heritage)), and municipal (of DGPC (Municipal Council - General Department for Cultural Heritage) authorities often do not successfully collaborate. Interviewees (IRPH and PROURB) argued that this dis-articulation has generated a large number of unregistered buildings and limited the efficient implementation of legislation in practice. They noted that land division has contributed not only to changing the spatial configuration of Rio but has created difficulties that go far beyond conservation. This suggests a conflict between the urban heritage values recognised in legislation and how value recognition plays out in practice.

Beirut is characterised by the opposite tendency. While Rio presents too many actors and the lack of coordination between them, Beirut reveals a system where the decision to value UHA can be overturned by one person. The Lebanese Council of Ministers pass legislation, but its implementation falls to the Ministry for Culture. Proceedings of conservation planning therefore depend greatly on the minister in charge and so are intimately tied to personal agendas and changing political will (Hamdan et al., 2012). The formality of policy and value are thus not immediately intertwined, the difficult and capricious reality of politics, especially when tied to an individual, can therefore disrupt this relationship. When regulation is not enforced, conservation is often rendered an even more political decision, especially in cities which are ultimately political actors (Tunbridge, 
1984). Actors may comply with a policy that is inconsistent with, even opposed to, their beliefs, or they may sidestep the implementation of policy because of their convictions (Bevir, Rhodes, and Weller 2003). The opportunities and constraints linked to conservation planning not only depend on how regulations are set up, but in what context and to what degree they are implemented. As Bevir, Rhodes, and Weller $(2003,193)$ argue 'we cannot properly understand a political practice solely by its legal character', and so we must attempt to consider how it actually plays out. Although regulation is often a key first step: it is difficult for conservation, unlike some other urban concerns, to be effected through informal means.

\subsection{The value of land vs. heritage value}

\subsubsection{The extent of conservation constraints}

The extent of the constraints these various conservation planning systems present are also unavoidably linked to the complexities at play between land use policy structures, its applications and how these vary between contexts (Watt et al. 2014; Vernières 2011; Holman \& Ahlfeldt 2015). To different degrees, depending on context, the benefits of urban heritage are often overrun by more pressing needs tied to urban growth and development pressures, resulting in conservation sometimes being a loosely integrated variable in planning - a luxury not necessarily being advocated as an intrinsic part of contemporary urban fabric (Tweed \& Sutherland, 2007; Watson, 2015).

English conservation planning is underlined by notions of compromise and balance. The tendency to use the word 'significance' in previous planning documents such as PPS5 and PPG15 changed to the predominant use of the word 'interest' in the NPPF, as an interviewee argued, implicitly altering the weight given to urban heritage assets (Historic England Interview). As noted by Historic England (2015b, 3) conservation is not a standalone exercise, it must be negotiated and balanced with other local and national priorities. Although the NPPF states that 'local planning authorities should set out a strategy for the conservation and enjoyment of the historic environment' in their Local Plan (Paragraph. 126 DCLG 2012, 15) and should recognise it as irreplaceable, the document also clearly addresses a negotiation between conservation of heritage assets and necessary developments (Paragraph. 61 DCLG 2012, 15). A scale with existence value on one side and direct use values of land on the other is thus established. A compromise is immediately put forward between the protection of urban heritage and the evolution of the modern city. As with most elements in the English system, which is based on case-law, this leaves a great amount of space for interpretation. Local Planning Authorities (LPAs), which hold planning control, are given the option of permitting partial loss of heritage in CAs according to their 
judgement. LPAs must, however, 'not permit loss of the whole or part of a heritage asset without taking all reasonable steps to ensure the new development will proceed after the loss has occurred' (Paragraph. 136, DCLG 2012, 15). Loss of existence value is thus only justified if direct use values of land are exploited.

Despite the NPPF stating that the planning system is to contribute to the achievement of sustainable development through its economic, social and environmental dimensions, many authors consider English planning to be fixed on a growth-imperative model wishing to limit further planning power (DCLG, 2012; R. Lee, 2011; Rydin, 2013). Centring on economic profit has made social constructs of the built environment such as urban heritage preservation unpopular, criticised as mechanisms hampering the market by restricting land supply and leading to rising house prices (Cheshire \& Hilber, 2008; Hilber, 2015). This 'negotiation' between conservation planning and development, is much rarer in the French or northern Italian systems, where the possibility of compromise especially in terms of new builds within UHAs is much more restricted. In fact, in comparing our three European systems, the strong tensions between conservation and growth, especially noted in London, seem disproportionate (Cheshire \& Dericks, 2014). Demolition and new build are controlled in the English context, but their local determination, available local resources and local values and attitudes create far more variation in the ultimate outcome of their conservation (Bottrill, 2005). Negotiation between conservation and development is much more widely found in our Global South case-studies and, though not part of this study, it must be said also in the southern Italian context.

The French system has often been criticised as presenting an arrangement characterised by too many checks and balances. The 2016 legislative amendment finally simplified and clarified things by eliminating the simultaneous imposition of codes (Ministère de la Culture et de la Communication, 2016). From 2016 onwards areas where two codes existed would be subject to the most restrictive only. For example, if a building is in a site inscrit and in the perimeter of a historic monument, it will only be subject to restrictions by the historic monument, because it is the most restrictive (Heritage code) (Figure 3). On the other hand, if the building is a site inscrit but not in the perimeter of a monument it will be subject to the environmental code. Other simplifications to the system are also occurring, not only with the limitation of the 500m perimeter, as discussed in section 3.2.1. of this paper, but with the first de-designation of an urban heritage asset in Paris. For example, a public consultation is was recently underway to de-designate the entrance to the Bois de Boulogne in proximity of the Suresnes bridge (Prefet de la Région 
d'lle de France, 2017). Interviewees confirmed that there is little reason for this listing, designated in 1922, to exist (MSD France Interview). The cast iron bridge, built between 1873 and 1874, was destroyed and replaced by a reinforced concrete bridge in 1951. In addition, this area of the city has been profoundly transformed, to the point that the epicentre of the perimeter of protection turns out to be a major road. This consultation on de-designation has been made possible by recent changes to the environmental code as it relates to the total or partial de-designation of a monument of a site classé.

The Italian system is also often characterised by too much restriction, suggesting too high a price is legislatively placed on the existence value of all urban heritage. Owners usually prefer their buildings not to be within UHAs and work on properties within UHAs is often done without permission to avoid extra costs (ISTAT, 2015). The Italian conservation planning is, however, also characterised by institutional regional disparity, both in terms of amount of designations and in enforcement of regulation in practice. ISTAT (2013) statistics reveal the country's regional division resulting in different conditions of the urban historical environment. Northern cities such as Milan have 3 out of 4 historic buildings in an excellent or good condition whereas southern cities have fewer than half of all heritage assets in a good state (ISTAT, 2015). The Commissione Franceschini (1964) was the first governmental body to denounce the degradation, the state of abandonment and the lack of development of urban heritage in Italy in the 1960s. Today, while some cities adhere to the restrictive regulations, others, especially in southern regions are characterised by a laxer application of these and thus a deterioration of the historic environment.

There are many reasons why southern regions are characterised by degradation, amongst these are: lack of political will to enforce regulation, lack of compliance resulting in resident-led illegal amendments and construction and/or a lack of local investment in UHAs (Bonfantini 2012) (For a larger discussion, see Pietrostefani (2019)). Interviewees remarked that some regional governments have worked much more than others with regard to their historical urban environments. Clearly, there is a lack of geographical consistency within the system (MIBAC and UNESCO/ANCSA Interviews). In some regions, the Italian case presents an over estimation of intrinsic values of heritage which results in a very limited usage of its use values. While in others, lack of enforcement as well as residents and developers disrespecting regulation results in illegal amendments and modifications to historic properties and built environments.

This trend supports the notion that opportunities and constraints linked to planning will not only depend on how regulations are set up, but in what context and to 
what degree they are implemented and that it is often in this willingness to implement policy, or not, that we can also see value being expressed. The formality of policy and value are not immediately tied, the difficult reality of political activity and governance intervenes between them. When regulation is not enforced, conservation is in many ways a political decision, tied to the value of actors within cities with regulation enforced or ignored based on the values of these actors (Tunbridge, 1984). As Bevir, Rhodes, and Weller $(2003,193)$ argue 'we cannot properly understand a political practice solely by its legal character', and so we must attempt to consider how it actually plays out. In analysing how conservation planning compares between northern and southern cities, we must attempt to unpick the element of governance that follows regulation in the hierarchy of political will. As suggested by Balbo $(2014,282)$, we need to be aware in our reflection, of the reassessment of the government versus urban governance; in cases where state governance is lacking, it may have been taken over by independent entities.

In our southern case-studies, we become more aware of the luxury of conservation in light of the greater need for urban development in fast-growing cities (Cheng et al., 2017; S. L. Lee, 1996). We are also continuously reminded of the pronounced economic and political choice to value land and economic speculation, over valuing urban heritage. Therefore, conservation planning in our southern cities is characterised by a pitched conflict between the value of land for redevelopment and the value of heritage practiced through regulation. Having discussed the extent of the constraints of northern conservation planning, we now find ourselves unpicking the degree to which an absence of constraints illustrate how urban heritage is valued within our southern contexts.

\subsubsection{Playing the Land Exploitation Game}

As conservation often entails keeping exploitation rates low, maintaining conservation areas in highly dense cities is a challenge in contexts of rapid urbanisation. This marks a difficulty in integrating heritage in urban policies in practice (Batista \& Macedo, 2010; Castriota, 2008). Within this climate, a cleverly-contextual legal attempts have been made in various contexts to protect the few remaining heritage buildings by utilising the nation's tendency towards land exploitation.

In Beirut, this approach is closely tied to the TCE (Total Coefficient of Exploitation) of the city, which determines how high one can build on a parcel of land. In 1971 Beirut changed the TCE of its city centre to 6, approximately 160-180m high, equivalent to the buildings of La Défense in Paris (Ashkar, 2018; Hanna, 2010). This very high coefficient was 
later suppressed, and planning law accorded no coefficients or formal height restrictions: the sky was the limit. This law approved on 12/10/2017, allows for the Transfer of Development Rights (TDR), meaning that an owner may sell the undevelopable portion of their protected parcel (air rights) to someone else who is then allowed to build the same quanta of development elsewhere in the city (Hilton, 2017; Saade, 2017). This allows owners to keep their heritage building while benefiting from the development value of their land. In return, selling the TDR gives owners the necessary revenue to engage in renovating their building (Beirut Municipality Interview) (Saade, 2017). Although this approach in no way attempts to preserve the few remaining heritage areas as a whole, it is a last resort to protect individual buildings. We cannot comment on the implementation of this legislation, as the government has yet to ratify it, similar mechanisms have been successful in contexts presenting similar land exploitation difficulties. In Brazil, the City Statue includes clauses regarding the purchase and transfer of property rights for buildings having to maintain their original form (R. C. M. Da Silva, 2012). The TDR makes possible to transfer or sell the unused portion of a building to a site in another area defined by the city's urban master plan (R. C. M. Da Silva, 2012). An Interviewee commented that such mechanisms should be further developed in contexts like Rio de Janeiro to create a better balance between those who profit from urban development and heritage building owners, for a more equal city paradigm (Rio Municipality Interview). This regulation offers an excellent window into locally derived values that seek to both preserve heritage as a living memory in the city, but also acknowledge the financial costs of doing so.

Such alternative legislations have been pursued to counter tendencies towards demolition. In the 1940s, the creation of the Avenida Presidente Vargas in Rio, justified the demolition of hundreds of townhouses, entire blocks of colonial fabric, a ninety-meter strip of one of Rio's parks (Campo de Santana), and the dismantling of two churches (Borde \& Sampaio, 2012; Ribeiro \& Simao, 2014). Praça Onze, another space of great symbolic value for Carioca urban culture, a site of carnival parades and a public space for immigrants and newly freed slaves, was also eliminated. The decision was controversial as it prioritised urban redevelopment and modern aesthetics over an urban fabric with evident sociocultural value (Borde and Sampaio, 2011). This was the beginning of a trend, which flourished in the 1970s, where high-rise buildings became symbols of progress and modernity (R. C. M. Da Silva, 2012). As a consequence many important historical buildings were demolished and substituted by modern ones (Rojas, 1999). Accounts from the Monroe Palace demolition in 1975 frame it as an effort to remove decay and abandonment 
from the city, placing these values above the historic importance of the site (Paraizo, 2004). However, an interviewee (PROURB) argued that this, like many other examples, was just a justification for clearance, which concealed more speculative and political ambitions. Moreover, damage was not limited to buildings. In 8/18/2009 Judge Herman Benjamin in the Brazilian Superior Court of Justice stressed how damage is not limited to structural harm, but includes more systemic damage to the environment as a whole (Miranda, 2017). These comments were being applied to the irregular conduct of a realestate company in Rio de Janeiro who had damaged the green area of an UHA, affecting the environmental value of the location.

This tendency to demolish, indicating how land and its exploitation is valued more than urban heritage value, is also present in Beirut. Recent work by Gebara, Khechen, \& Marot (2016) maps Beirut's demolition-based urban restructuring where approximately $78 \%$ of authorised construction was based on redevelopment, much of this on plots that contained heritage buildings. This figure rises in the neighbourhoods of Mazraa ( $90 \%$ of urban reconstruction is demolition-based) and in the historic quarter of Zokak-El-Blat ( $85 \%$ demolition). This is also illustrated in Figure 7 in section 4.3.2. Owners of heritage buildings in Beirut often see no point in renovating in the absence of subsidies and given they are unable to increase ground rent from these buildings, they often engage in legal or illegal demolition (Krijnen, 2018b). This tendency towards demolition suggests that in many cases, land value and the economic benefits to be made from it trumps the preservation of urban heritage values. The economic and intrinsic values of urban heritage are secondary to economic exploitation of land and financial speculation (Figure 1) and the potential of urban heritage to create prestige or revenue is not taken into account, as the culture and local values of the market do not support this.

In the introduction of this paper we proposed that the more urban heritage is exploited, the greater the loss of its intrinsic value (Zouain, 2002, 221). Thus, to support a 'living' urban heritage, there is a constant search for equilibrium between the two curves that allows for economic benefit to occur and patrimony to be respected. However, while the over-regulation of urban heritage or 'museumifying' UHA may be argued for the cases of northern Italy and France (Choay, 1992), in our southern case-studies, economic exploitation does not come from the building itself but from the land it is built on (Ost, 2009). The greater the exploitation of land, the greater the loss of all heritage values, both intrinsic and economic, where a heritage asset's possible future value is lost (OECD, 2007). 


\subsubsection{Dissonance between legislation and practical urbanism}

In the 2000 s legislation for new building construction became more flexible in Rio, stimulating the construction business. Real-estate developers wanted to maximize legally permitted land use (R. C. M. Da Silva, 2012). Since 2005, the central area of Rio de Janeiro has therefore seen increasing real estate projects. State led infrastructure projects have also contributed to accelerating the processes of urban transformation (Borde \& Sampaio, 2012). Although many buildings escaped demolition through regulation, many others, especially in economically challenged UHAs suffered from deterioration and obsolescence. Townhouses in these areas are often internally demolished to respond to the expanding demand for parking, and given the growing demand for housing, old buildings in degraded conditions are often occupied (IPHAN Interview).

The port zone of Rio (APA SAGAS) for example retains significant historic references to quilombos communities (ex-slaves). However, it has undergone great transformation. Substandard and informal housing predominates in much of this area, with heritage buildings abandoned and degraded (PROURB Interview). The Municipality of Rio then pushed for rehabilitation of the district in an effort to reintegrate it in the more dynamic sections of the city through the Projeto Porto do Rio published in 2001 (Soares \& Moreira, 2007). The plan has been implemented very slowly and it is argued that the area's urban heritage is de-naturalised and under-protected because of Olympic investments (Borde \& Sampaio, 2012) (PROUB Interview). Moreover, the lack of public resources for social housing represent a great threat to the permanence of local families and heritage streets such as Rua São Francisco da Prainha.

In fact, although many neighbourhoods in Rio welcomed APACs for the protection they afford built heritage, in some areas there was fierce opposition. The elected mayor in 2001, Cesar Maia, promised a suspension of licensing of new buildings in his campaign, and once elected as he could not change legislation he declared an APAC though mayoral decree (R. C. M. Da Silva, 2012). The neighbourhood of Leblon was thus designated. This started a power struggle between local NGOs and pressure-groups and construction firms who argued this suffocated the real estate market and would bring unemployment and economic losses. Much of the local population was also not happy, as APAC prevented modifications to their properties and hindered them from selling (Rio Municipality Interview).

Similar examples exist in the Beiruti context. Real-estate promoters able to operate with impunity have destroyed many buildings with high heritage value (Akl \& Davie, 1999). In 2004, the Lebanese building law (Law 646/2004) allowed for more 
intensive land exploitation (Ashkar, 2011; Krijnen \& Fawaz, 2010), increasing potential ground rents, especially in areas of the city characterised by low-rise rent-controlled (often heritage) buildings (Krijnen, 2018a; Krijnen \& Fawaz, 2010). Real estate developers started acquiring multiple plots, merging these in order to create larger ones to circumvent maximum building heights (Krijnen, 2018a; Krijnen \& Fawaz, 2010). The economic logic of land thus became much stronger than the recognition of patrimonial value; urban heritage is in fact rarely exploited in a commercial logic through boutique hotels and restaurants in Beirut (Ziad El Samad, 2016; Zouain et al., 2011). As argued by Barton et el (2013), if a high proportion of a city's economy is linked to construction, net income sacrificed to conservation will be high and cities in urgent need of economic growth will not be willing to make the sacrifice. In 2017, the real estate sector made nearly $15 \%$ of the Lebanese GDP with no capital investment in infrastructure and transport (CEIC, 2017; Fransabank, 2017).

As in the case of Leblon in Rio, local NGOs, neighbourhood associations and academics have put pressure on the local government in Beirut in an attempt to halt new developments in neighbourhoods considered to have heritage value, even those not formally inscribed. So too in Mar Mikhael, heritage based activism was widespread (Ashkarian, 2012; Fawaz et al., 2018). However, given the lack of legislation or municipal will to limit high-rise development the neighbourhood's morphology has changed significantly (APLH Interview), as evidenced by the Laziza factory complex, the first brewery of the middle east, which was demolished in (2017) to construct high-end condos (Ghorayeb, 2017). In both Rio and Beirut, non-governmental and community based organisations have thus increasingly filled the role of government agencies in light of questionable enforcement or lack of legislation (R. C. M. Da Silva, 2012; Hanna, 2010). The necessity for civil action in both cases is warranted and again suggests that it is not possible to determine value purely through legislation (Rojas, 2002). In many ways, NGOs are leading the governance of conservation planning Balbo (2014, 282). Huybrechts \& Verdeil (2005) have argued that Lebanon is a weak state with a strong society: value is present but a pattern of appropriation not designation shows more about urban heritage value (Rautenberg, 2003). Heritage appropriation is key to survival of Lebanese urban heritage, despite this method's obvious limitations of being easily halted by government (CDR and CHUD Interviews).

\section{Conclusion}

The objective of our paper was the untangling of how conservation planning systems and the local value of urban heritage were linked across several different planning 
contexts in the Global North and the Global South. We illustrate the complexities of heritage conservation, its integration into planning regulation, the implementation of these regulations and ultimately what this tells us about how society defines value in the context of conservation. We did this through an analysis of five case studies located in both Global North and Global South cities so that the complexities of regulation and context could better emerge. As we have shown there is no simple model that is particularly Northern or Southern, nor is there any country specific model that stays fixed overtime. Planning culture and by extension the expression of it through policy is as changeable as societal values themselves (Sanyal, 2005). Variegation always exists.

What this means for planning and more specifically conservation planning is nonetheless interesting. All of our cases began their journeys from similar points of departure, but each then proceeded in slightly different directions based on local contexts, producing different results. This is perhaps not unexpected, but it lends further weight to the work that eschews ideas that patrimonialisation is a European ideal merely applied in colonial contexts (Choay, 1992). While it may be true that 'heritage creation' emerged first in Europe, the development of regulations, the implementation of these rules and the histories and communities surrounding them are very much local and therefore produce place specific outcomes. We contend that the embedded histories of urbanism, planning regulation and the invention of a conceptualisation of what heritage means develop both separately and in parallel in each nation state. Whether urban planning and its practice links itself to the destruction of urban heritage ensembles or whether it attempts to conserve them, the concept of heritage emerges as a factor in opposition to dominant real estate models by becoming either an obstacle to the pursuit of economic value or an element that needs to be factored into the conservation of the intrinsic value of heritage. It is here, in this urban land nexus (Scott \& Storper, 2015) that we can begin to see the value judgements exercised in the application of planning policy.

In practice, conservation planning assumes many different meanings, bound in local context and the operation of the planning systems more broadly. Societal values impact planning decisions and in turn the outcomes of these decisions, further embed societal values until these values are disrupted through internal or external events. Assuming that any one model can describe a Global North or a Global South perspective underplays circumstantial histories. We contend that unpicking these processes through a close reading of the legislative development of regulation and its implementation (or not) illuminates the tensions between the desire to develop for economic value or conserve 
based on intrinsic value provides academics and planners a window with which to view how value is expressed.

\section{References}

Afonso da Silva, J. (1968). Aplicabilidade das normas constitucionais (Editôra Revista dos Tribunais (ed.)).

Ahlfeldt, G. M., \& Holman, N. (2015). No escape? The coordination problem in heritage preservation. Environment and Planning A, 47(1), 172-187.

Akl, Z., \& Davie, M. F. (1999). Questions sur le Patrimoine Architectural et Urbain au Liban. ALBA URBAMA.

Albrecht, B., \& Magrin, A. (2015). Esportare il centro storico. Catalogo della mostra. Fondazione la triennale di Milano.

APUR. (2004). Protéger le patrimoine et favoriser la création architecturale. Special PLU.

Ashkar, H. (2011). The Role of the State in initiating gentrification: the case of the neighbourhoofd of Achrafieh. Lebanese University.

Ashkar, H. (2018). The role of laws and regulations in shaping gentrification: The view from Beirut. City, 22(3), 341-357. https://doi.org/10.1080/13604813.2018.1484641

Ashkarian, V. (2012). Le développement local du quartier Mar Mikhaël, Beyrouth. Université Libanaise, Institut des Beaux Arts.

Ashworth, G. (2011). Preservation, Conservation and Heritage: Approaches to the Past in the Present through the Built Environment. Asian Anthropology, 10(1), 1-18. https://doi.org/10.1080/1683478x.2011.10552601

Assemblée Nationale. (2017). Loi du 21 avril 1906 organisant la protection des sites et monuments naturels de caractère artistique. http://www.assemblee-nationale.fr/12/evenements/salon-desmaires/dates_cles/protection-sites-1906-1.asp

Audrerie, D. (2000). La protection du patrimoine culturel dans les pays francophones (Editions $\operatorname{ESTEM}($ ed.)).

Balbo, M. (2012). The medina : the restoration and conservation of historic Islamic cities. I.B. Tauris.

Balbo, M. (2014). Beyond the city of developing countries. The new urban order of the 'emerging city.' Planning Theory, 13(3), 269-287. https://doi.org/10.1177/1473095213496098

Balducci, A., \& Gaeta, L. (2015). L'Urbanistica Italiana nel Mondo: Contributi e debiti culturali. Donzelli Editore.

Bandarin, F. (2015). Urban Conservation and the End of Planning Introduction. In Reconnecting the City (pp. 1-16). John Wiley \& Sons, Ltd.

Barton, D. N. ., Blumentrath, S., Bernasconi, P., Pinto, R., \& Tobar, D. (2013). Guidelines for opportunity cost evaluation of conservation policy instruments (Issue 11).

Batista, V. O., \& Macedo, C. L. (2010). Cultural heritage in Brazilian legislation and areas of protection of cultural environment in Rio de Janeiro. Politicas Culturais Em Revista, 2(3), 96120.

Bernier, L., Dormaels, M., \& Le Fur, Y. (2012). La patrimonialisation de l'urbain —Presses de I'Université du Québec (Presses de l'Université de Québec (ed.)). http://www.puq.ca/catalogue/livres/patrimonialisation-urbain-2453.html

Bevir, M., \& Rhodes, R. A. W. (2006). Governance stories - London School of Economics and Political Science (Routledge (ed.)).

Bevir, M., Rhodes, R. A. W., \& Weller, P. (2003). Comparative governance: prospects and lessons. Public Administration, 81(1), 191-210. https://doi.org/10.1111/1467-9299.00342

Bishwapriya, S. (2005). Hybrid Planning Cultures: The Search for the Global Cultural Commons. In B. Sanyal (Ed.), Comparative planning cultures (pp. 3-28). Routledge.

Bleyon, J.-B. (1981). L'Urbanisme et la Protection des Sites. La Sauvegarde du Patrimoine architectural urbain. Librarie générale de droit et de jurisprudence.

Bonfantini, B. (2012). Planning the historic centres in Italy : for a critical outline. Planum. The Journal of Urbanism, 2(25), 1-19.

Bonfantini, B. (2013). Centri Storici: infrastrutture per l'urbanità contemporanea. Territorio, 64, 153-161.

Bonfantini, B. (2015). Historic Urbanscapes for Tomorrow, Two Italian Cases: Genoa and Bologna. 
European Spatial Research and Policy, 22(2), 57-71. https://doi.org/10.1515/esrp-2015-0025

Booth, P. (2011). Culture, planning and path dependence: Some reflections on the problems of comparison. Town Planning Review, 82(1), 13-28. https://doi.org/10.3828/tpr.2011.4

Borde, A. de L. P., \& Sampaio, A. da R. (2012). Politicas Urbanas e Patrimonio Cultural: Paradoxos e Dialogos na Area Urbana Central do Rio De Janeiro. 54 Congreso Internacional Da Americanista.

Bottrill, C. (2005). Homes in Historic Conservation Areas in Great Britain: calculating the proportion of residential dwellings in conservation areas. Environmental Change Institute, August, 1-11. http://www.eci.ox.ac.uk/research/energy/downloads/40house/background_doc_K.pdf

Burke, G. (1976). Townscapes. Harmondsworth: Penguin.

Camara dos Deputados. (2010). Legislação sobre Patrimônio Cultural (Edicoes Ca).

Campos-Venuti, G., \& Oliva, F. (1993). Cinquant'anni di urbanistica in Italia : 1942-1992 (Laterza (ed.)).

Canani, A. S. K. B. (2005). Herança, sacralidade e poder: sobre as diferentes categorias do patrimônio histórico e cultural no Brasil. Horizontes Antropológicos, 11(23), 163-175.

Carughi, U. (2012). Maledetti Vincoli: La tutela dell'architettura contemporanea (Umberto Allemandi \& C. (ed.)).

Castriota, L. B. (2008). Intervenções sobre o patrimônio urbano: modelos e perspectivas. Fórum Patrimônio: Ambiente Construído e Patrimônio Sustentável, 1(1), 9-31. http://forumpatrimonio.com.br/seer/index.php/forum_patrimonio/article/viewFile/59/54

CEIC. (2017). Lebanon GDP: GVA: Real Estate |Economic Indicators. https://www.ceicdata.com/indicator/lebanon/data/gdp-gva-real-estate

Cheng, S., Yu, Y., \& Li, K. (2017). Historic conservation in rapid urbanization: a case study of the Hankow historic concession area. Journal of Urban Design, 22(4), 433-454. https://doi.org/10.1080/13574809.2017.1289064

Cheshire, P., \& Dericks, G. (2014). Iconic Design as Deadweight Loss : Rent Acquisition by Design in the Constrained London Office Market. SERC Discussion Paper.

Cheshire, P., \& Hilber, C. (2008). Office Space Supply Restrictions in Britain : The Political Economy of Market Revenge and Office Space Supply Restrictions in Britain : The Political Economy of Market Revenge. 44(117), 1-46.

Choay, F. (1992). L'allégorie du patrimoine (Seuil). AT/Patrimoine

Clarke, N. (2012). Actually existing comparative urbanism: Limitation and cosmopolitanism in North-South interurban partnerships. Urban Geography, 33(6), 796-815. https://doi.org/10.2747/0272-3638.33.6.796

Cornu, M. (2003). Patrimoine architectural, urbain et paysager : enjeux juridiques et dynamiques territoriales : colloque des 6, 7 et 8 décembre 2001, Lyon (Direction de l'architecture et du patrimoine du Ministère de la culture et de la Communication (ed.)). l'Harmattan. http://catalogue.bnf.fr/ark:/12148/cb39017571d

Cornu, M., Fromageau, J., \& Wallaert, C. (2012). Dictionnaire comparé du droit du patrimoine culturel (Centre de recherches sur le droit du patrimoine culturel (ed.)). CNRS Éditions. http://catalogue.bnf.fr/ark:/12148/cb42733629p

Cornu, M., Negri, V., Bady, J.-P., \& Leniaud, J.-M. (2013). 1913 Genèse d'une loi sur les monuments historiques: Mémoire des grandes lois patrimoniales (La Documentation Française (ed.)).

Cosi, D. (2008). Diritto dei beni e delle attività culturali (Aracne (ed.)).

Council of European Union. (2014). Conclusions on cultural heritage as a strategic resource for a sustainable Europe. 32(0), 1-7. https://www.consilium.europa.eu/uedocs/cms_data/docs/pressdata/en/educ/142705.pdf

Council of Ministers Lebanese Republic. (2010). Proceedings of meeting of the Council of Ministers, Lebanon. 19.

Creswell, J. (2009). Research Design: Qualitative, Quantitative, and Mixed Methods Approaches. SAGE.

Da Silva, R. C. M. (2012). Politicas para a preservaçao do patrimonio cultural em face do desenvolvimento urbano no Rio de Janeiro. In R. L. Cavallazzi \& R. C. Paraizo (Eds.), Patrimonio, ambiente e sociedad: novos desafios espaciais (PROURB, pp. 117-133).

Dalmas, L., Geronimi, V., Noël, J.-F., \& Tsang King Sang, J. (2015). Economic evaluation of urban heritage: An inclusive approach under a sustainability perspective. Journal of Cultural Heritage, 16(5), 681-687. https://doi.org/10.1016/j.culher.2015.01.009

Davie, M. F. (2001). Beyrouth 1825-1975: un siècle et demi d'urbanisme. Ordre des Ingénieurs et 
Architectes de Beyrouth.

Davie, M. F. (2004). Le patrimoine architectural et urbain au Liban: prise de conscience, idéologies de protection et éléments de prospective. https://hal.archives-ouvertes.fr/hal-01078936

DCLG. (1994). Planning Policy Guidance 15 : Planning and the historic Environment.

DCLG. (2010). Planning Policy Statement 5: Planning for the Historic Environment.

DCLG. (2012). National Planning Policy Framework. Communities and Local Government.

Devernois, N., Muller, S., \& Le Bihan, G. (2014). Gestion du patrimoine urbain et revitalisation des quartiers anciens : l'éclairage de l'expérience française. In AFD (Ed.), A Savoir.

Dolowitz, D. P., \& Marsh, D. (2000). Learning from Abroad: The Role of Policy Transfer in Contemporary Policy-Making. Governance, 13(1), 5-23. https://doi.org/10.1111/0952-1895.00121

Dos Santos, H. M., \& Telles, M. F. de P. (2017). Livros do Tombo. http://portal.iphan.gov.br/uploads/ckfinder/arquivos/Livros do Tombo Dicionário Iphan.pdf

Earl, J. (2015). Building conservation philosophy.

Fantini, S. (2014). II centro storico come bene paesaggistico a valenza culturale. Aedon.

Fawaz, M., Krijnen, M., \& El Samad, D. (2018). A property framework for understanding gentrification: Ownership patterns and the transformations of Mar Mikhael, Beirut. City, 22(3), 358-374. https://doi.org/10.1080/13604813.2018.1484642

Finco, A., \& Nijkamp, P. (2001). Pathways to urban sustainability. Journal of Environmental Policy and Planning, 3(4), 289-302. https://doi.org/10.1002/jepp.94

Fischfisch, A. (2011). Formes urbaines et architecturales de Beyrouth (depuis le XIXe siècle jusqu'à nos jours). ALBA.

Flyvbjerg, B. (2006). Five Misunderstandings About Case-Study Research. Qualitative Inquiry, 12(2), 219-245. https://doi.org/10.1177/1077800405284363

Fransabank. (2017). Lebanon's Real Estate Sector: Current Status and Future Trend (Issue March).

Friedmann, J. (2005). Planning cultures in transition. In B. Sanyal (Ed.), Comparative planning cultures (pp. 29-44). Routledge.

Friedmann, John. (2008). The Uses of Planning Theory: A Bibliographic Essay. Journal of Planning Education and Research, 28cne(2), 247-257. https://doi.org/10.1177/0739456X08325220

Friedmann, John. (2011). Insurgencies : essays in planning theory. Routledge.

Gayego, V. (2014). Cultural Heritage, City, Sustainability: What is the Role of Urban Legislation in Preservation and Development? Ambiente \& Sociedade, XVII(2), 89-110.

Gazzetta Ufficiale. (2009). La Giunta Regional: dichiarazione di notevole interesse pubblico del Quartiere Brera in comune di Milano.

http://www.gazzettaufficiale.it/atto/serie_generale/caricaArticoloDefault/originario?atto.dat aPubblicazioneGazzetta $=2010-01-$

22\&atto.codiceRedazionale $=10$ A00540\&atto.tipoProvvedimento=DELIBERAZIONE

Gebara, H., Khechen, M., \& Marot, B. (2016). Mapping New Constructions in Beirut (2000-2013). Jadaliyya. http://www.jadaliyya.com/Details/33751/Mapping-New-Constructions-in-Beirut2000-2013

Ghorayeb, J. (2017, March 27). Historic Laziza brewery demolition begins, can it be stopped? BeirutReport.

Giannini, M. S. (1976). I beni culturali. Rivista Trimestrale Di Diritto Pubblico, 4.

GLA. (2012). London View Management Framework SPG (Issue march). https://www.london.gov.uk/priorities/planning/supplementary-planning-guidance/viewmanagement

Glaeser, E. L., Kolko, J., \& Saiz, A. (2001). Consumer city. Journal of Economic Geography, 1(1), 27-50. https://doi.org/10.1093/jeg/1.1.27

Guimaraens, C. (2002). Paradoxos Entrelaçados: as torres para o futuro e a tradição nacional. UFRJ.

Habitat III. (2015). Issue Papers 4 - Urban Culture and Heritage Issue Paper (Issue May).

Hamdan, A., Lamy-Willing, S., \& Yazigi, S. (2012). Axes de réflexions pour une réforme du droit de l'urbanisme au Liban. ALBA, Université de Balamand. http://www.alba.edu.lb/french/axesreflexion-reforme-droit-urbanisme-liban

Hamin, E. M. (2003). Mojave lands : interpretive planning and the national preserve. Johns Hopkins University Press.

Hanna, M. (2010). L'Echec des politiques patrimoniales au Liban: Acteurs et Enjeux.

Harris, N. (2013). Surveillance, social control and planning: citizen-engagement in the detection and investigation of breaches of planning regulations. Town Planning Review, 84(2), 171-196. 
https://doi.org/10.3828/tpr.2013.11

Hilber, C. (2015). UK Housing and Planning Policies: the evidence from economic research (Issue May). http://cep.lse.ac.uk/pubs/download/EA033.pdf

Hilton, D. (2017). Lebanon activists cite win for heritage preservation. Aljazeera. https://www.aljazeera.com/news/2017/10/171013114545683.html

Historic England. (2018). London's Image and Identity: Revisiting London's Cherished Views

Historic England. (2015a). Heritage Counts 2015: Caring for the Local historic environment. 2-15.

Historic England. (2015b). Managing Significance in Decision-Taking in the Historic Environment. Historic England \& Historic Environment Forum.

Historic England. (2015c). The Historic Environment in Local Plans (Historic England \& HIstoric Environment Forum (ed.)).

Holman, N. (2014). Like Mixing Oil and Water? The Take-Up of Sustainability in Hard-to-Reach Places--An East Texas Case Study. Journal of Planning Education and Research, 34(4), 420-432. https://doi.org/10.1177/0739456X14549468

Holman, N., Mossa, A., \& Pani, E. (2018). Planning, value(s) and the market: An analytic for "what comes next?" Environment and Planning A, 50(3), 608-626.

https://doi.org/10.1177/0308518X17749730

Huybrechts, E., \& Verdeil, É. (2005). Beyrouth entre reconstruction et métropolisation. Villes En Parallele, 32-33, 63-87.

IAU-IDF. (2013). Patrimoine bâti, identité et territoires. Les Cahiers, 167.

ICOMOS France. (2010). LE PATRIMOINE : UN MODĖLE DE DÉVELOPPEMENT DURABLE Quelles performances énergétiques pour le patrimoine architectural et urbain en Europe et en Méditerranée?

International Foundation for Art Research (IFAR). (2014). Country Summary-LEBANON. http://www.ifar.org/country_title.php?docid $=1309292450$

IRPH. (2018). Patrimonio Cultural Carioca. http://pcrj.maps.arcgis.com/apps/MapSeries/index.html?appid=d3906debb8724872a7a50608 d2fae 884

ISTAT. (2013). Paesaggio e patrimonio culturale. In Istituto nazionale di statistica (Ed.), Rapporto Bes: il benessere equo e sostenibile in Italia.

ISTAT. (2015). Paesaggio e patrimonio culturale. In Rapporto Bes: il benessere equo e sostenibile in Italia.

James, O., \& Lodge, M. (2003). The Limitations of 'Policy Transfer and 'Lesson Drawing for Public Policy Research. Political Studies Review, 1(2), 179-193. https://doi.org/10.1111/1478-9299.t01-100003

Keller, D., Koch, M., \& Selle, K. (1996). 'Either/or' and 'and': first impressions of a journey into the planning cultures of four countries. Planning Perspectives, 11(1), 41-54.

Knieling, J., \& Othengrafen, F. (2015). Planning Culture-A Concept to Explain the Evolution of Planning Policies and Processes in Europe? European Planning Studies, 23(11), 2133-2147. https://doi.org/10.1080/09654313.2015.1018404

Krijnen, M. (2010). Facilitating real estate development in Beirut: A peculiar case of neoliberal public policy (Issue October). American Univeristy of Beirut.

Krijnen, M. (2018a). Beirut and the creation of the rent gap. Urban Geography, oo(00), 1-19. https://doi.org/10.1080/02723638.2018.1433925

Krijnen, M. (2018b). Gentrification and the creation and formation of rent gaps: Opening up gentrification theory to global forces of urban change. City, 22(3), 437-446. https://doi.org/10.1080/13604813.2018.1472461

Krijnen, M., \& Fawaz, M. (2010). Exception as the Rule: High-End Developments in Neoliberal Beirut. Built Environment, 36(2), 245-259. https://doi.org/10.2148/benv.36.2.245

Larkham, P. J. (1992). Conservation and the changing urban landscape. Progress in Planning, 37(PART 2), 83-181. https://doi.org/10.1016/0305-9006(92)90010-D

Le Louarn, P. (2011). Le patrimoine culturel et la décentralisation. Presses Universitaires de Rennes. http://pur-editions.fr/detail.php?idOuv=2578

Lee, R. (2006). The ordinary economy: tangled up in values and geography. Transactions of the Institute of British Geographers, 31(4), 413-432. https://doi.org/10.1111/j.14755661.2006.00223.x

Lee, R. (2011). Ordinary economic geographies: can economic geographies be non-economic? In 
Sage (Ed.), The SAGE Handbook of Economic Geography (p. 368). Sage.

Lee, S. L. (1996). Urban conservation policy and the preservation of historical and cultural heritage. Cities, 13(6), 399-409. https://doi.org/10.1016/0264-2751(96)00027-3

Lennox, R. (2013). Political Advocacy for the Historic Environment: A Public Policy Review of England's National Planning Policy Framework. The Historic Environment: Policy \& Practice, 4(1), 35-49. https://doi.org/10.1179/1756750513Z.00000000021

Licciardi, G., \& Amirtahmasebi, R. (2012). The Economics of Uniqueness: Investing in Historic City Cores and Cultural Heritage Assets for Sustainable Development (The World Bank: Urban Development Series (ed.)).

Lowenthal, D. (1985). The past is a foreign country. Cambridge University Press.

McFarlane, C. (2010). The Comparative City: Knowledge, Learning, Urbanism. International Journal of Urban and Regional Research, 34(4), 725-742. https://doi.org/10.1111/j.14682427.2010.00917.x

Mehl-Schouder, M.-C., Driard, J.-H., \& Ibanez, P. (2015). Code de l'urbanisme: commenté (Dalloz (ed.)).

Ministère de la Culture et de la Communication. (2013). Patrimoine et architecture: Chiffres Clés 2013 - Statistiques de la Culture.

Ministère de la Culture et de la Communication. (2016). Loi création : une nouvelle ambition pour la culture. http://www.culturecommunication.gouv.fr/Actualites/En-continu/Loi-creation-unenouvelle-ambition-pour-la-culture

Ministère de la Culture et de la Communication - Direction Générale des Patrimoines. (2012). Fiche Pratique 01 - Travaux en espaces protégés.

Ministero dei beni culturali e delle attività culturali e del turismo. (2017). Vincoli in Rete. http://vincoliinrete.beniculturali.it/VincolilnRete/vir/utente/login\#

Ministero dei Beni e della Attività Culturali e del Turismo. (2016). SITAP. http://www.sitap.beniculturali.it/

Ministero dei beni e delle attività culturali e del turismo. (2016). Vincoli in Rete. http://vincoliinrete.beniculturali.it/VincolilnRete/vir/utente/login

Ministero dei Beni e le Attività Culturali. (2016). Istituto Centrale per il Catalogo e la Documentazione. http://www.iccd.beniculturali.it/

Minnery, J., Storey, D., \& Setyono, J. (2012). Lost in Translation? Comparing Planning Responses to Urban Growth in the Global North and South. Urban Geography, 33(6), 850-865. https://doi.org/10.2747/0272-3638.33.6.850

Mioni, A., \& Pedrazzini, L. (2005). Valorizzazione dei centri storici. Criteri e indirizzi per i piccoli e medi comuni lombardi (Franco Angeli (ed.)). http://www.dastu.polimi.it/index.php?id=833

Miranda, M. P. de S. (2017). Lei do Tombamento completa 80 anos, mas continua atual. Consultor Juridico. https://www.conjur.com.br/2017-dez-09/ambiente-juridico-lei-tombamentocompleta-80-anos-continua-atual

Morpugno, D. (2014). Il valore del centro Storico-Artistico: prezzi edonici a Perugia, Bologna e Trieste [Politecnico di Milano]. https://doi.org/10.1017/CBO9781107415324.004

Nadin, V., \& Stead, D. (2008). European Spatial Planning Systems, Social Models and Learning. DisP - The Planning Review, 44(172), 35-47. https://doi.org/10.1080/02513625.2008.10557001

Navrud, S., \& Ready, R. C. (2002). Valuing cultural heritage : applying environmental valuation techniques to historic buildings, monuments, and artifacts. Edward Elgar.

Code du patrimoine, (2010) (testimony of Vincent Negri \& Marie Cornu).

Newman, P., \& Thornley, A. (1996). Urban planning in Europe : international competition, national systems and planning projects (Routledge (ed.)).

OECD. (2007). Assessing Environmental Policies. Policy Brief.

Olivetti, L., Della Pepa, C., Abram, J., Guccione, M., Guido, M., Prosperetti, F., \& Spitz, E. (2008). Strategie di valorizzazione e gestione per il patrimonio architettonico: sguardi e proposte (Fondazione Adriano Olivetti (ed.)).

Ost, C. (2009). A Guide for Heritage Economics in Historic Cities: Values, Indicators, Maps and Policies Research Report. The Getty Conservation Institute.

Othengrafen, F., \& Reimer, M. (2013). The Embeddedness of Planning in Cultural Contexts: Theoretical Foundations for the Analysis of Dynamic Planning Cultures. Environment and Planning A: Economy and Space, 45(6), 1269-1284. https://doi.org/10.1068/a45131

Pagiola, S. (1996). Economic Analysis of Investments in Cultural Heritage: Insights from 
Environmental Economics. Environment Department, World Bank.

Palermo, P. C., \& Ponzini, D. (2010). Spatial planning and urban development : critical perspectives. Springer.

Palermo, P. C., \& Ponzini, D. (2012). At the Crossroads between Urban Planning and Urban Design: Critical Lessons from Three Italian Case Studies. Planning Theory \& Practice, 13(3), 445-460. https://doi.org/10.1080/14649357.2012.701661

Pani, E. (2017). Economic geographies of value revisited. Geography Compass, 11(9), 1-13. https://doi.org/10.1111/gec3.12326

Paraizo, R. C. (2004). Urban heritage representations in hyperdocuments: the Monroe Palace in Rio de Janeiro. City \& Time, 1(1), 39-51.

Pendlebury, J. (2009). Conservation in the Age of Consensus (Routledge (ed.)).

Pietrostefani, E. (2015). L'évaluation du patrimoine urbain: le cas libanais. Techniques Financières et Développement, 1, 65-79.

https://scholar.google.co.uk/citations?view_op=view_citation\&hl=en\&user=VVogR6sAAAAJ \&citation_for_view=VVogR6sAAAAJ:u-x6o $\overline{8}$ ySGosC

Pietrostefani, E. (2019). Conservation planning and informal institutions: heterogenous patterns in Italian cities. Working Paper.

Planchet, P. (2009). Droit de l'urbanisme et protection du patrimoine enjeux et pratiques. Le Moniteur.

Poulot, D. (2006). Une histoire du patrimoine en Occident, XVIIle-XXIe siècle : du monument aux valeurs. Presses universitaires de France.

Prefet de la Région d'lle de France. (2017). Dossier d'enquête Publique: declassement du Site "Entrée du Bois de Boulogne aux Abord du Point Suresnes.

Decreto-lei 25/37 | Decreto-lei ${ }^{\circ} 25$, de 30 de novembro de 1937, (1937). https://presrepublica.jusbrasil.com.br/legislacao/109250/decreto-lei-25-37

Provins, A., Ozdemiroglu, E., Johns, H., Pearce, D., Mourato, S., \& Chowne, P. (2005). Valuation of the Historic Environment (EFTEC (ed.); Issue July). https://doi.org/10.1016/j.progress.2008.01.001

Provins, A., Pearce, D., Ozdemiroglu, E., Mourato, S., \& Morse-Jones, S. (2008). Valuation of the historic environment: The scope for using economic valuation evidence in the appraisal of heritage-related projects. Progress in Planning, 69(4), 131-175. https://doi.org/10.1016/j.progress.2008.01.001

Puzon, K. (2019). Saving Beirut: heritage and the city. International Journal of Heritage Studies, 25(9), 914-925. https://doi.org/10.1080/13527258.2017.1413672

Raspi Serra, J. (1990). Argan G. C. Il concetto di 'centro storico. In Guerini studio (Ed.), Il concetto di centro storico : ricerca archeologica, recupero, conservazione, riuso, protezione dei beni culturali (pp. 15-21).

Rautenberg, M. (2003). La rupture patrimoniale (E. P. Cresson (ed.)). http://www.culture.gouv.fr/mpe/dossiers/parutions_signalees/2003_rup_patrimoniale.htm

Rhodes, R. A. W. (1997). Understanding governance : policy networks, governance, reflexivity and accountability. Open University Press .

Rhodes, R. A. W. (2007). Understanding Governance: Ten Years On. Organization Studies, 28(8), 1243-1264. https://doi.org/10.1177/0170840607076586

Ribeiro, C. R., \& Simao, M. C. R. (2014). Relações e contradições : direito à cidade e patrimônio urbano. Encontro Da Associação Nacional de Pesquisa e Pós-Graduação Em Arquitetura e Urbanismo.

Rizzo, I., \& Throsby, D. (2006). Chapter 28 Cultural Heritage: Economic Analysis and Public Policy (pp. 983-1016). https://doi.org/10.1016/S1574-0676(06)01028-3

Rizzo, I., \& Towse, R. (2002). The Organisation and Finance of Cultural Heritage in Sicily. Edward Elgar Publishing. http://explore.bl.uk/primo_library/libweb/action/display.do?tabs=moreTab\&ct=display\&fn=se arch\&doc=ETOCCN044409215\&ind $x=1 \&$ reclds $=E T O C C N 044409215 \&$ recld $x s=0$ \&element $I d=0$ \&renderMode=poppedOut\&displayMode $=$ full \&frbrVersion $=\& d s c n t=0 \& s c p . s c p s=s c o p e:(B L C$ ONTENT\%25

Rojas, E. (1999). Old cities, new assets : preserving Latin America's urban heritage. Inter-American Development Bank. https://books.google.co.uk/books/about/Old_Cities_New_Assets.html?id=AN1PAAAAMAAJ\& 
redir_esc=y

Rojas, E. (2002). Urban Heritage Conservation in Latin America and the Caribbean A Task for All Social Actors.

Rouillon, V. (2014). Vers l'évaporation des ZPPAUP et des AVAP ? Table ronde sur les dispositifs de protection du patrimoine. La Lettre d'Echanges $N^{\circ} 121$.

Roy, A. (2009). The 21st-Century Metropolis: New geographies of theory. Regional Studies, 43(6), 819-830. https://doi.org/10.1080/00343400701809665

Roy, A. (2011). Slumdog Cities: Rethinking Subaltern Urbanism. International Journal of Urban and Regional Research, 35(2), 223-238. https://doi.org/10.1111/j.1468-2427.2011.01051.x

Rydin, Y. (2013). The future of planning : beyond growth dependence. Policy Press.

Saade, T. (2017, October 31). A Success For Beirut's Heritage, But Not Yet A Victory. Beirut Today. http://beirut-today.com/2017/10/31/success-beiruts-heritage-not-yet-victory/

Sanyal, B. (2005). Comparative planning cultures. Routledge.

Savini, F., \& Aalbers, M. B. (2016). The de-contextualisation of land use planning through financialisation: Urban redevelopment in Milan. European Urban and Regional Studies, 23(4), 878-894. https://doi.org/10.1177/0969776415585887

Scattoni, P., \& Falco, E. (2011). Why Italian planning is worth studying. Italian Journal of Planning Practice, I(1), 4-32. http://ijpp.uniroma1.it/index.php/it/article/view/4

Scott, A., \& Storper, M. (2014). The Nature of Cities: The Scope and Limits of Urban Theory. International Journal of Urban and Regional Research. https://doi.org/10.1111/1468-2427.12134

Serageldin, I. (1999). Very Special Places: the Architecture and Economics of Intervening in Historic Cities (ed. Culture in Sustainable Development) (The World Bank (ed.)). http://wwwwds.worldbank.org/external/default/WDSContentServer/WDSP/IB/1999/09/14/000094946_9 905260827175/Rendered/PDF/multi_page.pdf

Silva, F. F. da. (2012). Cidades Brasileiras e o Patrimônio Cultural da Humanidade (EDUSP - Editora da Universidade de São Paulo (ed.)). http://www.edusp.com.br/loja/produto/896/cidadesbrasileiras-e-o-patrimonio-cultural-da-humanidade,-as

Simon, V. K., \& Braathen, E. (2019). Collective heritage and urban politics: an uncertain future for the living culture of Rio de Janeiro? International Journal of Heritage Studies, 25(4), 380-394. https://doi.org/10.1080/13527258.2018.1493700

Smith, L. (2006). Uses of heritage. Routledge, Taylor \& Francis Group.

Soares, E. M. A. da S., \& Moreira, F. D. (2007). Preservação do patrimônio cultural e reabilitação urbana: o caso da zona portuária da cidade do Rio de Janeiro. Da Vinci, 4(1), 101-120.

Tabet. (2001). Beyrouth: Portrait de Ville.

Thomas, G. (2005). The Qualitative Foundations of Political Science Methodology. Perspectives on Politics , 3 (4), 855-866. Perspectives on Politics, 3(4), 855-866.

Throsby, D. (2010). The Economics of Cultural Policy. Cambridge University Press.

Toubekias, G., \& Dentzer, J.-M. (2009). Report of the joint ICOMOS/World Heritage Centre reactive monitoring mission to TYRE, Lebanon.

Tuan, T. H., \& Navrud, S. (2007). Valuing cultural heritage in developing countries : comparing and pooling contingent valuation and choice modelling estimates. Environ Resource Econ, 38, 5169. https://doi.org/10.1007/s10640-006-9056-5

Tunbridge, J. E. (1984). Whose Heritage to conserve? Cross-cultral reflections on political dominance and urban heritage conservation. Canadian Geographer, XXVIII(2).

Tweed, C., \& Sutherland, M. (2007). Built cultural heritage and sustainable urban development. Landscape and Urban Planning, 83(1), 62-69. https://doi.org/10.1016/j.landurbplan.2007.05.008

Tyan, M. (2012). La protection du patrimoine bâti au Liban: Cadre juridique, acteurs et enjeux. Modern Heritage Observatory Reunion.

Civic Amenities Act 1967, Chapter 69, 1 (1967) (testimony of UK Parliament). http://www.legislation.gov.uk/ukpga/1967/69

UN-Habitat. (2011). Lebanon Urban Profile: a Desk Review Report.

UNESCO. (2012). Rio de Janeiro: Carioca Landscapes between the Mountain and the Sea. https://whc.unesco.org/en/list/1100/

Valler, D., \& Phelps, N. A. (2018). Framing the Future: On Local Planning Cultures and Legacies. Planning Theory and Practice, 19(5), 698-716. https://doi.org/10.1080/14649357.2018.1537448

Vecco, M. (2007). Economie du patrimoine monumentale (Economica (ed.)). 
Vernières, M. (2011). Patrimoine et développement: Etudes pluridisciplinaires (GEMDEV - Karthala (ed.)). http://www.gemdev.org/publications/patrimoine/patrimoine_tab.htm

Vernieres, M., Patin, V., Mengin, C., Geronimi, V., Dalmas, L., Noel, J., Tsang, J., \& Sang, K. (2012). Méthodologies d'évaluation économique du patrimoine urbain : une approche par la soutenabilité économique du patrimoine urbain. In A. F. de Développement (Ed.), A Savoir.

Watson, V. (2015). Seeing from the South : Refocusing Urban Planning on the Globe's Central Urban Issues. Urban Studies, 46(October 2009), 2259-2275. https://doi.org/10.1177/0042098009342598

Watt, T., Pincetl, S., \& Joa, M. (2014). The Push and Pull of Land Use Policy : Reconstructing 150 Years of Development and Conservation Land Acquisition. 9(7). https://doi.org/10.1371/journal.pone.0103489

Ziad El Samad, D. (2016). Property, Housing and Processes of Gentrification: A Case Study of the Neighbourhood of Mar Mikhael (Beirut). American University of Beirut.

Zouain, G. (2002). Le patrimoine culturel dans l'économie: éléments d'une réflexion. Travaux et Jours, 69, 203-224.

Zouain, G., Liatard, F., \& Fournier, Z. (2011). Les industries créatives dans la ville: Le cas du quartier de Mar-Mikhayel à Beyrouth. Travaux et Jours, 85, 139-185. 


\section{Appendix: The politics of conservation planning: a comparative study of urban heritage making}

Tab. 1 List of Interviews

\begin{tabular}{|c|c|c|c|c|}
\hline$\#$ & Institution or Organisation & Ref. within text & Country & City \\
\hline 1 & Historic England & Historic England & UK & London \\
\hline 2 & Greater London Authority & GLA 1 & UK & London \\
\hline 3 & Greater London Authority & $\begin{array}{l}\text { GLA } 2 \\
\text { Hackney }\end{array}$ & UK & London \\
\hline 4 & Hackney Borough - London & Borough & UK & London \\
\hline 5 & $\begin{array}{l}\text { Ministry of Cultural- National Directorate of Heritage and } \\
\text { Architecture }\end{array}$ & $\begin{array}{l}\text { Ministry of } \\
\text { Culture France }\end{array}$ & France & Paris \\
\hline 6 & $\begin{array}{l}\text { Territorial services of architecture and heritage (Services } \\
\text { Territoriaux de l'Architecture et du Patrimoine STAP) Paris } \\
\text { Territorial services of architecture and heritage Services }\end{array}$ & STAP Paris & France & Paris \\
\hline 7 & $\begin{array}{l}\text { Territoriaux de l'Architecture et du Patrimoine STAP) Ile-de- } \\
\text { France }\end{array}$ & $\begin{array}{l}\text { STAP Ile-de- } \\
\text { France }\end{array}$ & France & $\begin{array}{l}\text { Ile-de- } \\
\text { France }\end{array}$ \\
\hline 8 & Paris Town Hall (Mairie de Paris) & Paris Municipality & France & Paris \\
\hline 9 & $\begin{array}{l}\text { Ministry of Sustainable Development (Ministère de l'Écologie } \\
\text { et du Développement durable) }\end{array}$ & MSD France & France & $\begin{array}{l}\text { lle-de- } \\
\text { France }\end{array}$ \\
\hline 10 & IAUV (Academic) & IAUV & Italy & $\mathrm{GN} / \mathrm{GS}$ \\
\hline 11 & MiBAC Milano (Regional Ministry of Culture) & $\begin{array}{l}\text { MiBAC } \\
\text { Lombardy }\end{array}$ & Italy & Milano \\
\hline 12 & Lombary Regional Government & Region & Italy & Milano \\
\hline 13 & Urban heritage legislation expert & CLS & Italy & Milano \\
\hline 14 & Constitutional and urban heritage law expert & CE & Italy & Milano \\
\hline 15 & Politecnico di Milano expert & Politecnico & Italy & Milano \\
\hline 16 & Representative of UNESCO and ANCSA & UNESCO/ANCSA & Italy/France & Paris \\
\hline 18 & Cultural Heritage and Urban Development in Lebanon Project & CHUD & Lebanon & Beirut \\
\hline 19 & $\begin{array}{l}\text { Representative Permanent Delegation of Lebanon to UNESCO } \\
\text { Representative of the Association for the protection of }\end{array}$ & UNESCO-LB & Lebanon & Paris \\
\hline 20 & $\begin{array}{l}\text { Lebanese Heritage NGO } \\
\text { General Directorate of Antiquities, Lebanese Ministry of }\end{array}$ & APLH & Lebanon & Beirut \\
\hline 21 & $\begin{array}{l}\text { Culture } \\
\text { Project Manager at Council for Development and }\end{array}$ & DGA & Lebanon & Beirut \\
\hline 23 & Reconstruction & $\begin{array}{l}\text { CDR } \\
\text { Beirut }\end{array}$ & Lebanon & Beirut \\
\hline 24 & Beirut Municipality Council & Municipality & Lebanon & Beirut \\
\hline 25 & Save Beirut Heritage NGO & $\mathrm{SBH}$ & Lebanon & Beirut \\
\hline 26 & $\begin{array}{l}\text { Lebanese Order of Civil Engineers } \\
\text { Rio Heritage Institute (Instituto Rio Patrimonio da }\end{array}$ & LOCE & & \\
\hline 27 & Humanidade) & IRPH & Brazil & Rio \\
\hline 28 & National Historical and Artistic Heritage Institute Brazil & IPHAN & Brazil & Rio \\
\hline 29 & PROURB - Universidade Federal do Rio de Janeiro & PROURB & Brazil & Rio \\
\hline 30 & Municipality of Rio & Rio Municipality & Brazil & Rio \\
\hline
\end{tabular}

